\title{
Independent Technical Review of the Focused Feasibility Study and Proposed Plan for Designated Solid Waste Management Units Contributing to the Southwest Groundwater Plume at the Paducah Gaseous Diffusion Plant
}

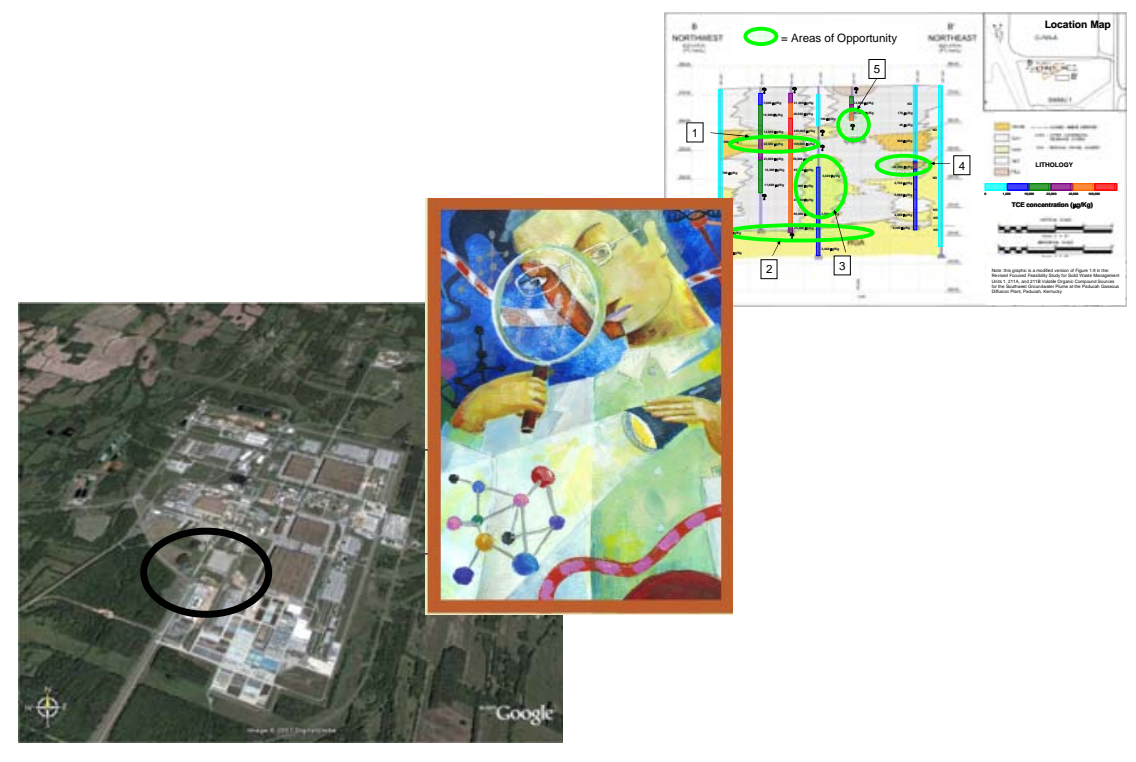

May 2011

Prepared for: The U.S. Department of Energy Office of Environmental Management Groundwater and Soil Remediation Technology (EM32), Washington, DC

Prepared by: The DOE EM Center for Sustainable Groundwater and Soil Solutions, Savannah River National Laboratory, Aiken SC

Technical content and coordination for this effort was provided by the Savannah River National Laboratory in conjunction with Contract No. DE-AC09-08SR22470 with the U.S. Department of Energy. 

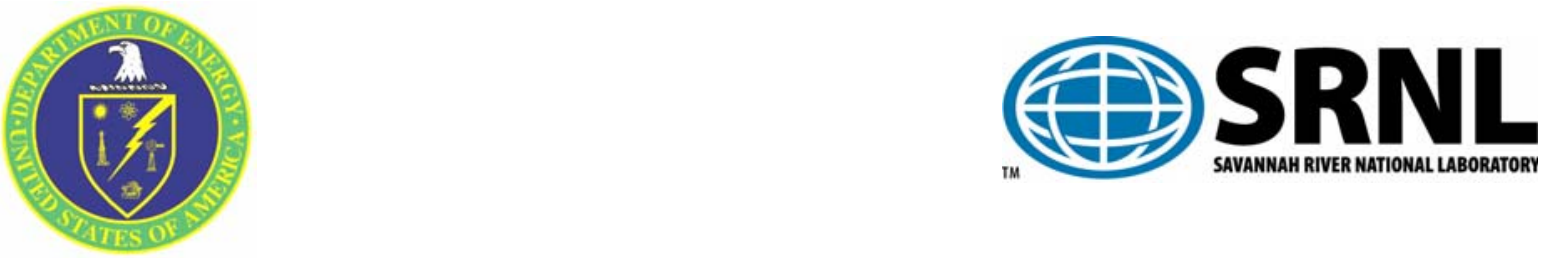

Cover Photo: Oblique view overhead photograph of the Department of Energy Paducah Gaseous Diffusion Plant near Paducah, KY and an example cross section from the Oil Landfarm in the Southwest Plume Area

\section{DISCLAIMER}

This work was prepared under an agreement with and funded by the U.S. Government. While the authors have taken care in the preparation of this report, neither the U. S. Government or its employees, nor any of its contractors, subcontractors or their employees, makes any express or implied: 1. warranty or assumes any legal liability for the accuracy, completeness, or for the use or results of such use of any information, product, or process disclosed; or 2. representation that such use or results of such use would not infringe privately owned rights; or 3. endorsement or recommendation of any specifically identified commercial product, process, or service. Any views and opinions of authors expressed in this work do not necessarily state or reflect those of the United States Government, or its contractors, or subcontractors.

Printed in the United States of America

Prepared For

U.S. Department of Energy

Office of Engineering and Technology 
SRNL-STI-2011-00290

\title{
Independent Technical Review of the Focused Feasibility Study and Proposed Plan for Designated Solid Waste Management Units* Contributing to the Southwest Groundwater Plume at the Paducah Gaseous Diffusion Plant
}

\author{
Authors: \\ Dr.Brian B Looney (Technical Lead, Savannah River National Laboratory) \\ Dr. Joseph Rossabi (Redox-Tech, LLC) \\ Mark B. Amidon (Savannah River National Laboratory) \\ Dr. Lloyd (Bo)Stewart (Praxis Environmental Technologies, Inc.) \\ Carol A. Eddy-Dilek (Team Coordinator, Savannah River National Laboratory)
}

Prepared for

Department of Energy (DOE) Office of Groundwater and

Soil Remediation

Washington, D.C.

May 2011

* Volatile Organic Compound Sources at Solid Waste Management Units 1, 211A, 211B, and Part of 102

Technical content and coordination for this effort was provided by the Savannah River National Laboratory in conjunction with Contract No. DE-AC09-08SR22470 with the U.S. Department of Energy. 
\{Blank page $\}$ 


\section{Table of Contents}

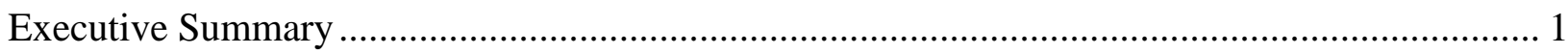

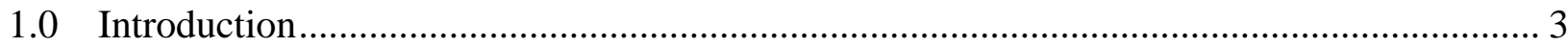

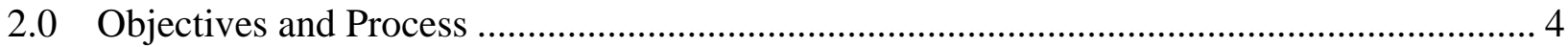

3.0 ITR Summary of SW Plume Background and History ................................................ 5

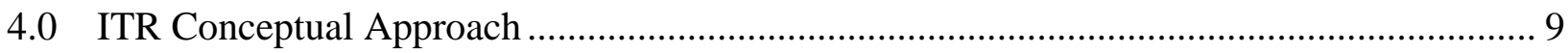

Anatomy of a contaminated site - the technology matching process ......................... 9

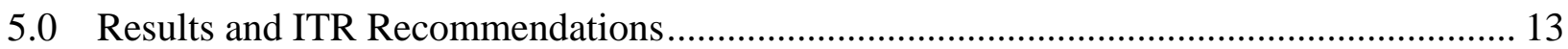

General ITR Assessment of Technology Selection in the FFS / PP ........................ 13

Recommendation on the use of technology classes versus brands ........................... 13

Better Matching of Technologies to Source Geometry and Lithostratigraphy........... 15

Soil Vapor Extraction - "SVE Lite” .................................................................. 19

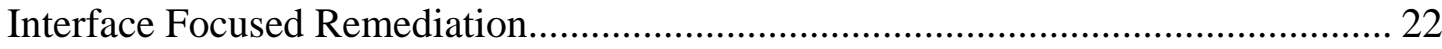

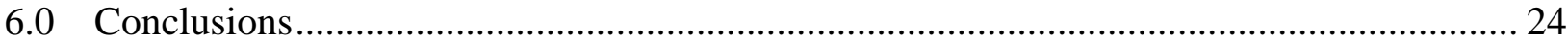

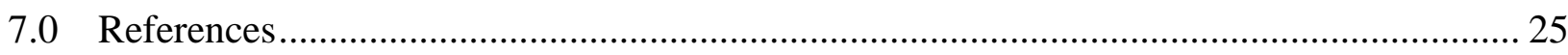

A Appendix - Independent Review Team Statement of Work .......................................... 27

B Appendix - Independent Review Team Members ...................................................... 30

C Appendix - Extended Evaluation of Soil Vapor Extraction............................................ 37 


\section{Acronyms and Abbreviations}

\begin{tabular}{|c|c|}
\hline$\%$ & percent \\
\hline $\mathrm{cu}$ & cubic (as in cubic feet, cubic meters, etc.) \\
\hline CY & calendar year \\
\hline DNAPL & dense nonaqueous phase liquid \\
\hline DOE & U.S. Department of Energy \\
\hline EISB & enhanced in situ bioremedation \\
\hline EM & Environmental Management \\
\hline EM-30 & DOE Office of Groundwater and Soil Remediation \\
\hline EPA & US Environmental Protection Agency \\
\hline FFS & Focused Feasibility Study \\
\hline $\mathrm{ft}$ & feet \\
\hline FY & fiscal year \\
\hline gpm & gallons per minute \\
\hline ITR & Independent Technical Review team \\
\hline $\mathrm{Kg}$ & Kilograms \\
\hline $\mathrm{L}$ & liters \\
\hline $\mathrm{lb}$ & pound \\
\hline LUC & Land Use Control \\
\hline msl & mean sea level \\
\hline NAPL & nonaqueous phase liquid \\
\hline OU & Operable Unit \\
\hline PGDP & Portsmouth Gaseous Diffusion Plant \\
\hline $\mathrm{PP}$ & Proposed Plan \\
\hline PPPO & Portsmouth Paducah Project Office \\
\hline PRG & preliminary remediation goal \\
\hline RCRA & Resource Conservation and Recovery Act \\
\hline RDSI & Remedial Design Site Investigation \\
\hline RGA & Regional Gravel Aquifer \\
\hline scfm & standard cubic feet per minute \\
\hline SI & Site Investigation Report \\
\hline SVE & Soil Vapor Extraction \\
\hline SW & Southwest \\
\hline${ }^{99}$ Tc & technetium-99 \\
\hline TCE & trichloroethene \\
\hline SWMU & Solid Waste Management Unit \\
\hline UCRS & Upper Continental Recharge System \\
\hline VOC & volatile organic contaminant \\
\hline$\mu g / \mathrm{kg}$ & micrograms of contaminant per Kg of dry soil \\
\hline$\mu g / L$ & micrograms of contaminant per liter of water \\
\hline WAG & Waste Area Grouping \\
\hline wt & weight \\
\hline ZVI & zero valent iron \\
\hline
\end{tabular}




\section{Executive Summary}

The U. S. Department of Energy (DOE) is currently developing a proposed plan (PP) for remediation of designated sources of volatile organic compounds (VOCs) that contribute contamination to the Southwest (SW) Groundwater Plume at the Paducah Gaseous Diffusion Plant (PGDP), in Paducah, Kentucky. Specifically, the PP presents "preferred alternatives" for remediation of residual VOCs in soil and sediments underlying the Oil Landfarm (Solid Waste Management Unit, SWMU, 1) and the C-720 Building spill sites (SWMU 211A/211B). Because of the importance of the proposed actions, DOE-EM assembled an Independent Technical Review (ITR) team at the request of PGDP that was tasked with providing input and assistance in finalizing the PP. The overarching findings of the review panel are summarized below:

\section{Positives:}

0 The PP (and the supporting focused feasibility study and site investigation reports) represents a tremendous amount of work. In general, the ITR commends the quantity and quality of characterization data, and the use of the data in developing remediation plans.

0 The ITR generally supports the classes of technologies considered as options for remediation of sources feeding the SW plume (see comments below with recommendations to improve the matching of technology implementation to site specific conditions).

o The ITR supports the "area closure" paradigm (e.g., addressing the various SW plume sources as a group rather than piecemeal).

Issues / Recommendations:

o The PP favors land-use-controls (LUCs), Alternative 2, for the C-720 Building spill sites (SWMU 211A/211B). The selection of this type of "minimal action" strategy increases the need to provide well substantiated and compelling modeling, as well as setting up actionable contingencies. The ITR found the modeling results to be reasonable but the models provided equivocal support for LUCs and little information was provided about contingencies. The ITR concluded that the technical case for LUCs is in a grey area - LUCs may be appropriate, but DOE should consider the possibility of implementing potential low-cost remedial technologies (e.g., a limited soil vapor extraction, SVE) that were not evaluated in the PP.

o The PP favors enhanced in situ bioremediation (EISB) at the Oil Landfarm (SWMU 1). The ITR believes that this is a viable selection but recommends considering/developing a lower cost deployment strategy, one that is better matched to the local lithostratigraphy. The ITR also recommends consideration of SVE as an alternative or adjunct technology.

o The ITR urges the contractors and DOE to focus more on matching technologies to site-specific conditions and "opportunities" in the Focused Feasibility Study (FFS) and PP evaluation

o In several cases, the PP specified several technology "brands", instead of technology classes. The ITR recommends that DOE consider minimizing project risk by identifying technology classes in the PP to maintain flexibility for 
performance optimization and cost savings. The scenarios assumed for costing and comparison in the FFS/PP can be presented only as exemplars of the class (avoiding sole source requirements, for example).

o The exclusion of a fourth SW Plume source area, the Contaminated Burial Yard/Area (SWMU 4), reduces the strategic effectiveness of the area closure paradigm and weakens the technical basis of the analysis/decision to provide a holistic solution. Importantly, however, SWMU4 is being addressed along with other landfill sites as a part of a different waste area group (WAG 3).

o The ITR identifies a variety of other minor topics (editorial, process, etc.).

For the C-720 Building spill sites (SWMU 211A/211B), the ITR provides specific information for a low cost SVE option - this "SVE Lite" option was projected to provide a reasonable level of performance and should be substantially less expensive than the multiphase extraction evaluated in the PP. This recommendation highlights a relatively important issue - if a minimal action alternative, such as LUCs, is potentially acceptable, there is little basis for implementing a robust and expensive exemplar of a competing technology class (e.g., multiphase extraction) as the comparison technology in a FFS and PP. Instead, a more modest exemplar (e.g., limited SVE) may be more appropriate -providing an appropriate level of performance at a reasonable cost.

The ITR provides several organizational / conceptual framework recommendations to assist in a more holistic and optimized strategy/design. For example, the ITR suggests that the "unique" site-specific lithologic structure, a relatively fine-grained zone (the Upper Continental Recharge System, "UCRS”) containing source VOCs overlying a coarse-grained Regional Gravel Aquifer ("RGA"), is a key and controlling feature of this site. The location, geometry, and character of that interface can be used to optimize treatment - for example to implement an "interface focused remediation" beneath the former Oil Landfarm (SWMU 1). A variety of specific remediation technology options were outlined by the ITR based on the refined conceptual model. For example, injection of zero valent iron (ZVI) and/or low density oils at the UCRS/RGA interface could be used to create a reaction and partitioning barrier that would mitigate contaminant transfer into the RGA. Note that this is an ITR developed "innovative technology" concept that could be used as an alternative to the enhanced in situ bioremediation design assumed for the Oil Landfarm (SWMU 1) in the FFS and PP. If selected, additional modeling and design would be required, as well as pilot or field design testing. For the Oil Landfarm (SWMU 1), focused treatment at the UCRS/RGA interface (depth of about $60 \mathrm{ft}$ ) could be combined with low-cost SVE in the vadose zone (e.g., 30 to $50 \mathrm{ft}$ depth), providing "defense in depth", site-matched and optimized actions, and reduced costs.

We encourage DOE and their contractors to consider the ITR findings and recommendations as they move forward. These are intended to aid the PGDP project team in executing a successful cleanup and in achieving environmental management (EM) and PGDP end-state goals. 


\subsection{Introduction}

The U. S. Department of Energy (DOE) is currently developing a Proposed Plan (PP) for remediation of designated sources of chlorinated solvents that contribute contamination to the Southwest (SW) Groundwater Plume at the Paducah Gaseous Diffusion Plant (PGDP), in Paducah, KY. The principal contaminants in the SW Plume are trichloroethene (TCE) and other volatile organic compounds (VOCs); these industrial solvents were used and disposed in various facilities and locations at PGDP. In the SW plume area, residual TCE sources are primarily in the fine-grained sediments of the Upper Continental Recharge System (UCRS), a partially saturated zone that delivers contaminants downward into the coarse-grained Regional Gravel Aquifer (RGA). The RGA serves as the significant lateral groundwater transport pathway for the plume. In the SW Plume area, the four main contributing TCE source units are:

1) Solid Waste Management Unit (SWMU) 1 / Oil Landfarm

2) C-720 Building TCE Northeast Spill Site (SWMU 211A)

3) C-720 Building TCE Southeast Spill Site (SWMU 211B)

4) C-747 Contaminated Burial Yard (SWMU 4).

The PP presents the Preferred Alternatives for remediation of VOCs in the UCRS at the Oil Landfarm and the C-720 Building spill sites. The basis for the PP is documented in a Focused Feasibility Study (FFS) (DOE, 2011) and a Site Investigation Report (SI) (DOE, 2007). The SW plume is currently within the boundaries of PGDP (i.e., does not extend off-site). Nonetheless, reasonable mitigation of the multiple contaminant sources contributing to the SW plume is one of the necessary components identified in the PGDP End State Vision (DOE, 2005). Because of the importance of the proposed actions DOE assembled an Independent Technical Review (ITR) team to provide input and assistance in finalizing the PP. 


\subsection{Objectives and Process}

The Statement of Work for the ITR is provided in Appendix A. This document requests that the ITR apply their expertise in, and prior experience with, groundwater remediation technologies to help DOE identify issues that are affecting or could affect the successful implementation of a selected remedy for several SW plume TCE/VOC sources. In addition, the ITR was tasked with developing recommendations that would result in costeffective resolution of any identified issues.

To meet these objectives, the ITR performed the following step-wise process.

o Review background materials concerning the Southwest Groundwater Plume sources

o Obtain additional information to complete the review of the FFS and PP

o Brief DOE and contractor staff on the results of their review

o Provide a report consisting of a written set of comments

The members of the ITR team have extensive experience and knowledge in source term characterization and delineation, remediation technology selection and implementation, safety, and cost estimation. The ITR team composition was:

o Dr.Brian B Looney (Savannah River National Laboratory)

o Dr. Joseph Rossabi (Redox-Tech, LLC)

o Mark B. Amidon (Savannah River National Laboratory)

o Dr. Lloyd (Bo)Stewart (Praxis Environmental Technologies, Inc.)

o Carol A. Eddy-Dilek (Savannah River National Laboratory)

A summary biography for each team member is provided in Appendix B. Brian Looney served as technical lead for this ITR. Carol Eddy-Dilek coordinated the team activities and served as liaison to the DOE Office of Environmental Management (DOE-EM), DOE Paducah Portsmouth Project Office (DOE-PPPO), DOE support contractor (Performance Results Corporation), and DOE operations contractor (LATA Environmental Services of Kentucky, LLC).

The ITR team would like to express their appreciation to DOE-EM for funding this effort and to DOE-PPPO and their contractors for providing the necessary data and for their openness to the concepts developed by the ITR. 


\subsection{ITR Summary of SW Plume Background and History}

The groundwater underlying various portions of the Paducah Gaseous Diffusion Plant (PGDP) is contaminated with chlorinated solvents; principally TCE (Figure 1), a common solvent. Lesser masses of other cVOCs are also present, as well as other contaminants such as technetium-99 $\left.{ }^{99} \mathrm{Tc}\right)$. Three groundwater plumes have been identified as a result of operations, maintenance, and waste disposal conducted at PGDP; they are the Northeast, Northwest, and Southwest Plumes (Figure 1). In contaminant source areas, notably near the C-400 Building, TCE is present as a dense non-aqueous phase liquid (DNAPL) in the silts and clays of the UCRS and in the underlying RGA. Residual DNAPL and high concentrations of contaminants in untreated, or partially treated, source zones continue to release contaminants slowly into the RGA and feed the primary and dilute portions of the groundwater plume.

Extensive site investigations have been performed at the PGDP to identify and delineate the sources to groundwater contamination. Remedial actions have been, and are currently being, implemented to reduce the impacts to groundwater and minimize risk to the public. Pump and treat operations are ongoing to capture and treat groundwater from the existing Northeast and Northwest TCE groundwater plumes. An electrical resistance heating project was implemented to address a significant TCE source that is contributing to the Northeast, Northwest, and Southwest Plumes at the C-400 Building (DOE 2009a). PGDP has performed several targeted removal/cleanup activities and a variety of other source treatment technologies have been evaluated and tested at this site.

The focus of this technical assistance is on the SW Plume PP was submitted to the Commonwealth of Kentucky and U.S. Environmental Protection Agency (EPA) in CY2011 that outlines PGDP's proposed remedial approach to addressing several designated VOC sources to the Southwest Plume (DOE 2011b). The potential sources to the Southwest Plume include the following (DOE 2007) (Figure 1):

1. SWMU 1 (C-747-C Oil Landfarm);

2. SWMU 211A and 211B (C-720 Building Northeast and Southeast, respectively);

3. SMWU 4 (C-747 Contaminated Burial Yard and C-748-B Burial Area); and

4. Storm sewer between the south side of the C-400 Building and Outfall 008. 


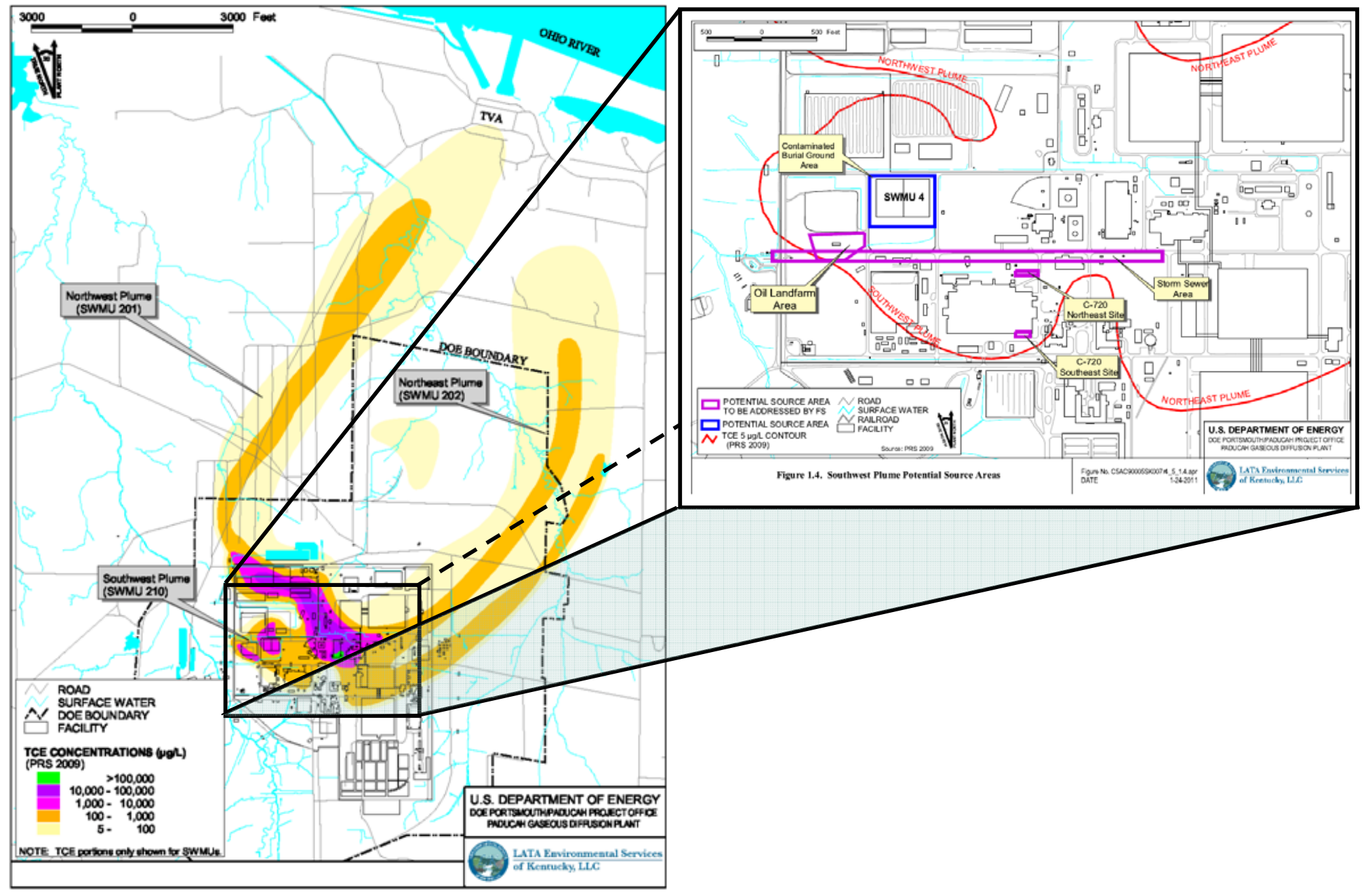

Figure 1. TCE Groundwater Plume at PGDP, 2009 shown with inset map of sources in SW Plume Area. (Source: DOE 2011a) 
Data for the Southwest Plume sources has been generated through a number of site characterization and investigation efforts. These include: Phase II Site Investigation (SI)(CH2MHill, 1992); Waste Area Grouping (WAG) 3 Remedial Investigation (RI) (DOE, 2001a); Data Gaps Investigation(DOE, 2001b); Southwest Plume SI (DOE, 2007); and Burial Grounds OU RI (DOE, 2009b). Site investigations confirmed the presence of TCE at four of the potential source areas: The Oil Landfarm (SWMU 1), the C-720 spill areas (SWMUs 211A, and 211B) and the Burial Yard/Area (SWMU 4). Three source areas are addressed in the SW Plume PP (SWMUs 1, 211A and 211B). SWMU 4 is not addressed in the current PP but is included in the Waste Area Group 4 (WAG 4) Burial Ground OU Feasibility Study. Note that SWMU 4 has been identified as a principal source of TCE and ${ }^{99} \mathrm{Tc}$ to Southwest Plume (DOE 2007). The storm sewer between the C-400 Building and Outfall 008 did not exhibit elevated levels of TCE and was not a significant source to the Southwest Plume and no further investigation or action is proposed (DOE 2011a).

The PP for the SW Plume (DOE, 2011a) is a component of the overall site wide strategy to clean up PGDP, to protect human health and the environment, and to achieve the desired end state (DOE, 2008). The site wide strategy addresses media-specific operable unit (OU) (e.g., groundwater OUs, surface water OUs, soils OUs, burial grounds OUs, and D\&D OUs). As discussed below, the subject PP addresses multiple sources of contamination to the SW plume and represents an "area closure" concept. The PP addresses three of the four sources where substantive TCE was measured. Importantly, SWMU 4 is not included in the subject PP, but is being addressed (in WAG 3, together with the "similar" landfill areas at PGDP) so that the overarching objectives of the site wide clean up strategy can be achieved. Nonetheless, the separation of SWMU 4 from other SW plume sources impairs the technical basis of the area closure analysis/decision to provide a holistic solution. This is particularly important when LUCs are selected for some sites since the most compelling "acceptable-risk" case for LUCs would include the composite impacts of all of the SW plume source areas to the identified receptors. 
The SW Plume PP is based on the FFS. In this document, potential treatment options for SMWUs 1, 211A, and 211B were evaluated (DOE 2011a). In the end, eight alternatives were selected for further evaluation and potential application (see box). Note that the technologies range from no further action to LUCs (monitoring), to a variety of active treatments (soil mixing, thermal and EISB). The eight alternatives were further evaluated based on long- and short-term effectiveness, reduction of toxicity, mobility, and volume, implementability, and cost. Using the resulting tabulations, the PP identifies and outlines the preferred alternative for TCE source reduction at the three subject source areas. For SWMU 1, "In situ source treatment using EISB with interim LUCs" was selected while for SWMUs 211A and 211B, "Long term monitoring with interim LUCs” was selected (DOE 2011b).
SWMUs 1, 211A and 211B Technologies Evaluated:

o No further action (“Alternative 1")

o Long term monitoring with interim LUCs (“Alternative 2")

o In situ source treatment using deep soil mixing with interim LUCs (“Alternative 3")

o Source removal and in situ chemical source treatment with interim LUCs (“Alternative 4")

o In situ thermal source treatment with interim LUCs ("Alternative 5")

o In situ source treatment using Liquid Atomized Injection with interim LUCs (“Alternative 6”)

o In situ soil flushing and source treatment using multiphase extraction with interim LUCs (“Alternative 7”)

o In situ source treatment using EISB with interim LUCs (“Alternative 8”)

\section{Southwest Plume Preferred PP Alternatives (DOE 2011b):}

1. SWMUs 211A and 211B (C-720 spill sites) - Long-Term Monitoring and Interim Land Use Controls (LUCs);

2. SWMU 1 (Oil Landfarm) - In Situ Source Treatment Using Enhanced In Situ Bioremediation and Interim LUCs.

3. SWMU 4 (Burial Yard) - To be addressed separately with other landfills

4. Storm sewer to Outfall 008 - No Further Action 


\subsection{ITR Conceptual Approach}

The PP (and FFS and underpinning SI reports) represent(s) a tremendous amount of work. The ITR commends these efforts. The ITR supports the "area closure" paradigm (e.g., addressing the various SW plume sources as a group rather than piecemeal). Finally, the ITR generally supports the classes of technologies considered as options for remediation of sources feeding the SW plume. The ITR felt that the site investigation efforts were relatively thorough, and the contaminant masses estimated for each source appear reasonable.

Nonetheless, the ITR process revealed a range of concerns and issues related to the PP for the SW Plume. These concerns/issues were generally related to inconsistencies and lack of attention to matching technologies to site-specific conditions. A clear conceptual approach for technology matching is crucial to the FFS/PP development process assuring that an appropriate (or the most appropriate) exemplar of each technology class is carried through the process. The following sections provide additional information on the ITR technology matching conceptual approach and extend the paradigm to the multiple sources in the SW Plume.

\section{Anatomy of a Contaminated Site - the Technology Matching Process}

Figure 2 depicts a conceptual diagram of a contaminated site that has impacted its surroundings - in this case, the underlying soil and groundwater. The three ovals—-the source zone, the primary contaminant plume, and the dilute fringe-represent different portions of the impacted environment; each zone has a different character. The source zone contains significant contamination in concentrated and hazardous forms. The source zone can contain materials such as DNAPL or highly contaminated sediments. The second oval, the primary contaminant plume, is comprised of contaminated groundwater or vapor than carries pollutants at lower levels, but levels that still represent a potentially significant present or future hazard. The third oval, the dilute fringe, contains contamination at relatively low concentrations but in large volumes of water.

Efficient and effective environmental cleanup requires matching the character of the cleanup and stabilization methods to the character of the target zone of contamination. Thus, aggressive and relatively expensive methods are often appropriate for the source zone, classical pump-and-treat methods are often good for the primary contamination zone, and various methods based on natural processes are often best for the dilute fringe. Figure 2 identifies several example technologies that are appropriate for each of the ovals. 


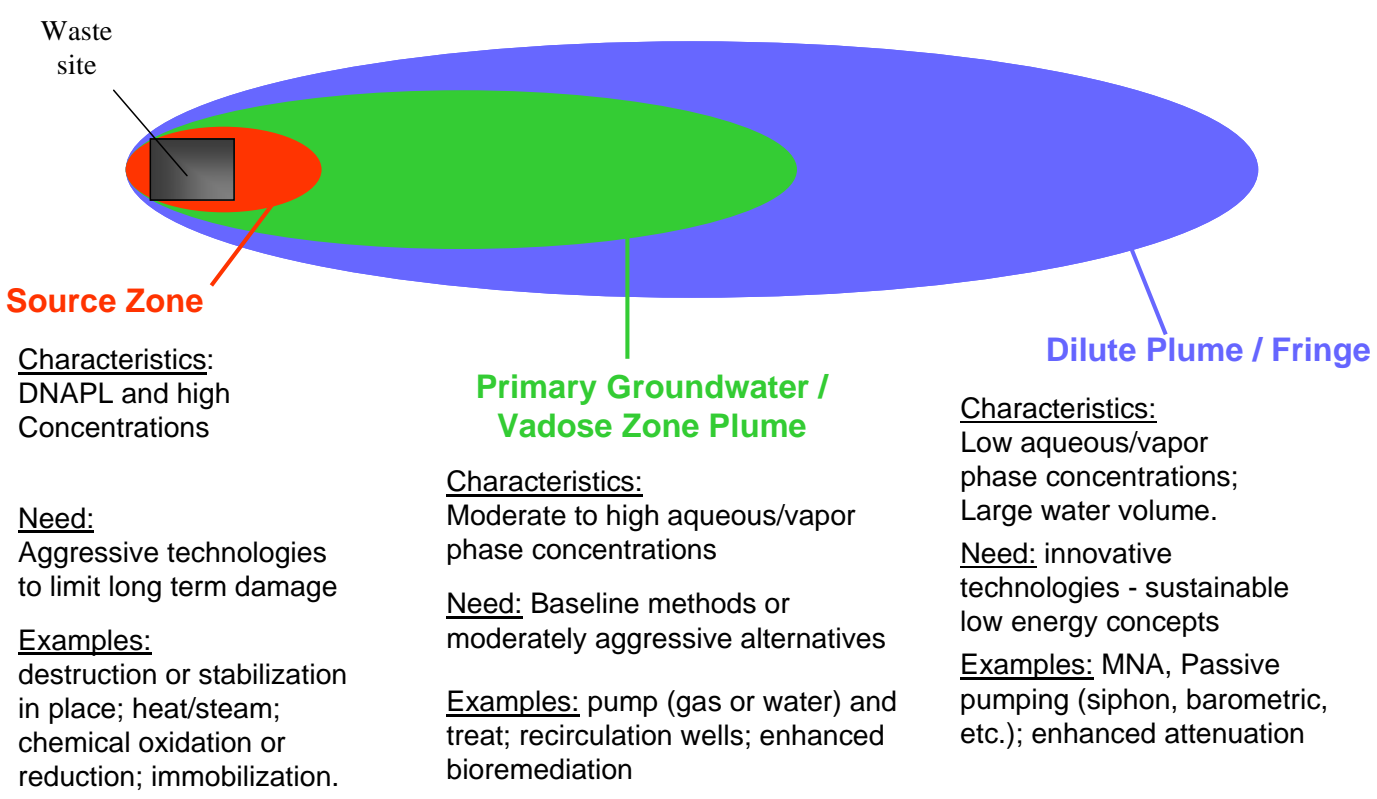

Figure 2. Simplified anatomy of a contaminated site.

In Figure 3, we have extended this conceptual model by identifying the cost basis for typical cleanup technologies. In the source zone, stabilization and removal methods are normally priced in terms of volume of soil or amount of contaminant in the treatment zone (\$ per cu yard, \$ per pound, and the like). The reference source zone technologies require aggressive access and subsequent use of targeted energy or chemical reagents. It is clear that in the source zone it is important to characterize the site in such a way that the precise location of the source zone is delineated as carefully as possible. This approach will reduce costs by focusing energy or reagent to areas where they are needed. Equally important, however, is the desire to minimize any undesired negative impacts (wasting energy, harming microbiological populations, etc.) associated with using aggressive remedies on regions without source level contamination. Similar to a doctor, environmental scientists should "first, do no harm."

In the primary contaminant plume, treatment technologies are normally priced in terms of the amount of water (or vapor) treated (e.g., \$ per thousand gallons). Thus, the goal of characterization is to define the flow directions and general plume structure to allow the most contaminant to be treated in the fewest "gallons". 


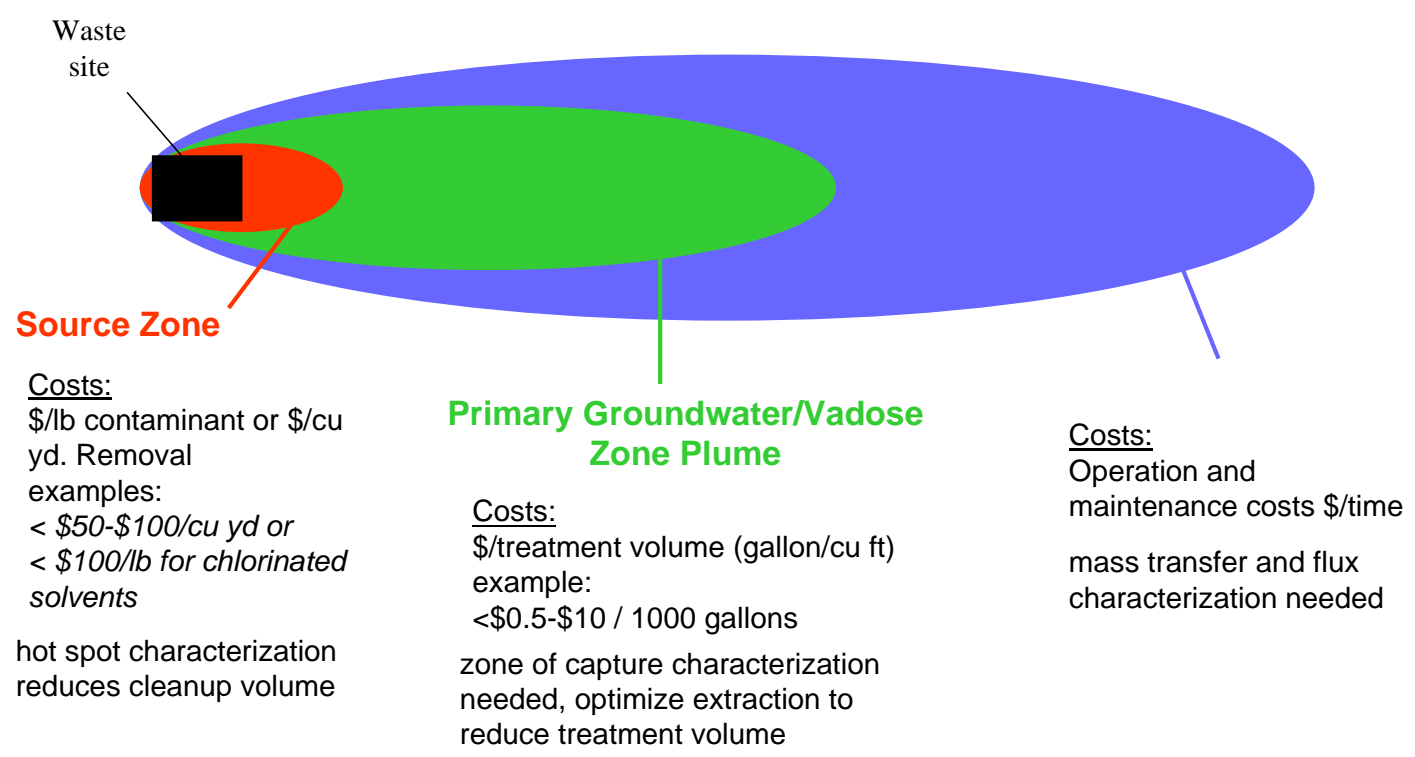

Figure 3. Treating a contaminated site

The dilute fringe contains low concentrations of contamination in large volumes of water. Thus, the best technologies for this zone are those that are priced in terms of time (e.g., \$ per year). To be successful, these technologies must rely on natural sustainable and measurable processes. This class of technology has gained recent regulatory support under terms such as "monitored natural attenuation”, "groundwater mixing zones, "alternate concentration limits, and in the case of the PGDP SW Plume "long-term monitoring and LUCs.” For the dilute fringe, technology selection is biased toward understanding the contaminant attenuation and stabilization in the subsurface. A second step is identifying engineering interventions, if needed, to maximize the performance and to assure that attenuation process will operate for extended periods. A critical requirement for these technologies is the development of logical and cost-effective monitoring strategies - this includes what will be monitored and why. This class of technologies normally requires that the monitoring data be assessed versus performance criteria with the potential requirement to implement a contingency if the criteria are exceeded. Importantly, these dilute fringe technologies would not generally be applicable to target areas with residual source material.

In a real setting, the actual size and shape of the target zone/plume impacts how distinct the actions to address the different zones need to be. Time is also a factor. Concentrations change, as cleanup progresses, so that dilute fringe technologies become appropriate for polishing areas that were formerly at higher concentrations (Figure 4). 

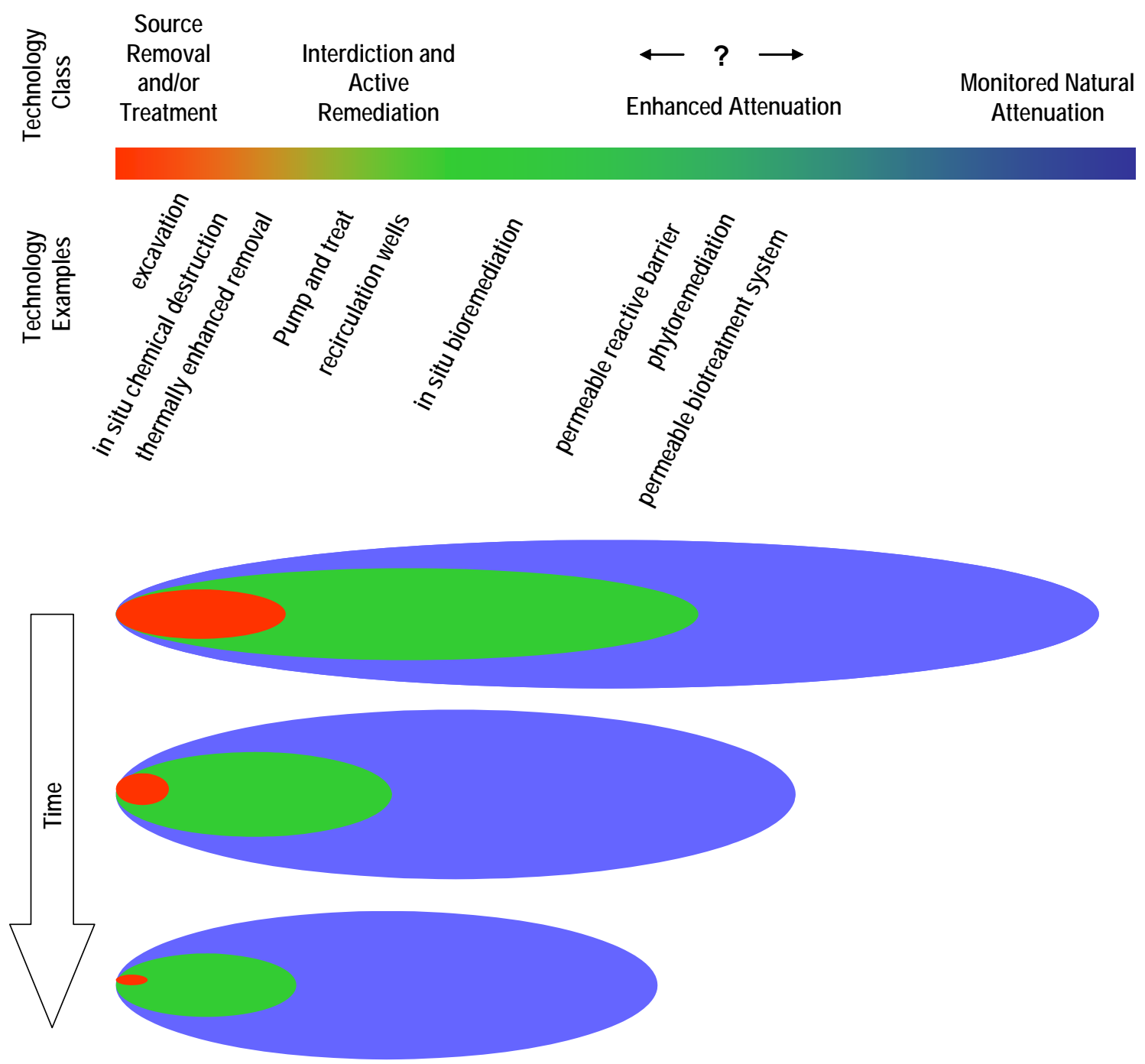

Figure 4. Matching technologies to site needs in space and time

The conceptual approach outlined above is relatively simple, but can be valuable in keeping feasibility studies and proposed plan efforts on course. Most importantly, the approach provides clarity in defining what technologies are really needed and helps the site owner, regulators and interested citizens develop a shared vision for the cleanup. Finally, this approach encourages implementation of one or more technologies that are well matched to the contaminant levels and the contaminant setting, and the contaminant location and geometry. The ultimate goal is implementation of actions that effectively and efficiently address a target problem. 


\subsection{Results and ITR Recommendations}

General ITR Assessment of Technology Selection in the FFS / PP for the SW Plume

The ITR urges DOE and its contractors to focus more on matching technologies to site specific conditions and "opportunities" in the FFS and PP evaluation

The PP favors long term monitoring and LUCs for the C-720 Building source areas. The selection of this type of "minimal action" strategy increases the need to provide well substantiated and compelling modeling, as well as setting up actionable contingencies. The ITR found the modeling results to be reasonable but the models provided equivocal support for LUCs and little information was provided about contingencies. As suggested by the ovals, selection of LUCs implies that the two C-720 source areas are in the distal/fringe "blue zone." While this might be the case, the ITR concluded that the technical case for LUCs falls in a grey area - LUCs may be appropriate, but DOE should consider the possibility of implementing potential low-cost remedial technologies (e.g., limited SVE) that were not explicitly evaluated in the PP.

The PP favors in situ bioremediation at the Oil Landfarm (SWMU 1). The ITR believes that this is a viable selection but recommends developing a lower cost deployment strategy, one that is better matched to the local lithostratigraphy. The ITR also recommends consideration of SVE as an alternative or adjunct technology. This is discussed in more detail below. Some of the other technologies considered in the proposed plan (e.g., Alternative 3 - deep soil mixing) are well matched to the lithological conditions at SWMU 1 and would help overcome mass transfer limitations; such technologies are relatively expensive, however, and should be selected only if effective alternatives that are less costly are not available.

\section{Recommendation on the use of technology classes versus brands}

The PP specified several "brands”, instead of technology classes, in the evaluation. The ITR recommends that DOE consider minimizing project risk by identifying technology classes in the PP to maintain flexibility for performance optimization and cost savings. The ITR recognizes that relatively specific assumptions must be made to complete an effective and defensible FFS and PP. However, the specific implementations assumed for costing and comparison in the FFS/PP can be presented only as exemplars of each class (avoiding sole source requirements, for example). Similarly, consideration of differing intensities of implementation might be considered as appropriate within the selected technology class.

This issue has been identified by previous ITR teams (e.g., thermal treatment for the C400 area). For the SW Plume PP, generic in situ thermal treatment is appropriately specified for alternative 5. Unfortunately, this was not generalized throughout the other alternatives. Alternative 6 repeats the historical path by specifying a brand (liquid atomized injection) offered by a single company that shows no clear advantage over other amendment distribution techniques. For alternative 7, soil flushing technologies were 
considered. The outcome of the FFS was a very specific combination of techniques without adequate consideration of various intensities of implementation (e.g., what could simple, low cost SVE achieve toward the remedial goals?). The addition of a surfactant greatly increases the complexity and cost of implementation compared to SVE alone. Finally, alternative 8 specifies a method for applying amendments (zigzag trench and gravity feed, fixed wells) to enhance biological remediation rather than focusing on generic enhancement of biological remediation applied to targeted zones in the subsurface.

Perhaps a more general way of listing the alternatives would be as follows:

Alternative 3: In Situ Source Treatment Using Deep Soil Mixing with Interim LUCs. This alternative consists of a remedial design site investigation (RDSI) to refine the extent of VOC contamination and quantify parameters for selecting and applying treatment reagents. The VOC contaminated soils will be mechanically mixed with a chemical reagent (oxidants, reductants, or other) to remediate the VOC contamination. .... "For cost and schedule estimating purposes, large diameter augers were assumed in the analysis, although there are other effective soil mixing methods. Final selection of a mixing technology would be performed as a component of the design process..." Note that language similar to the italicized statements can be developed for each alternative.

Alternative 4: Source Removal and In situ Chemical Source Treatment with Interim LUCs. This alternative consists of an RDSI for source area refinement, excavation of the sources, and treating the bottom $10 \mathrm{ft}$ to $13 \mathrm{ft}$ in situ with reagents that will remediate VOC contamination....

Alternative 6: In situ Source Treatment Using Amendment Injection with Interim LUCs. This alternative consists of an RDSI for source refinement and to quantify soil parameters for selecting and applying treatment reagents/amendments. Reagents/amendments would be injected at multiple depths in the subsurface based on the results of the RDSI for optimum distribution. ...

Alternative 8: In Situ Source Treatment Using EISB with Interim LUCs. Alternative 8 will consist of an RDSI for source refinement and quantification of soil parameters for bioremedial action. Enhanced bioremediation will be implemented by applying amendments to target zones at various depths in the UCRS determined by the RDSI. Multiple applications may be required. ... 
As an example of the paradigm recommended by the ITR, this section works through an example for the Oil Landfarm (SWMU 1). In the FFS, a key cross section documents the lithostratigraphy in the most contaminated area. This is reproduced below (Figure 5).

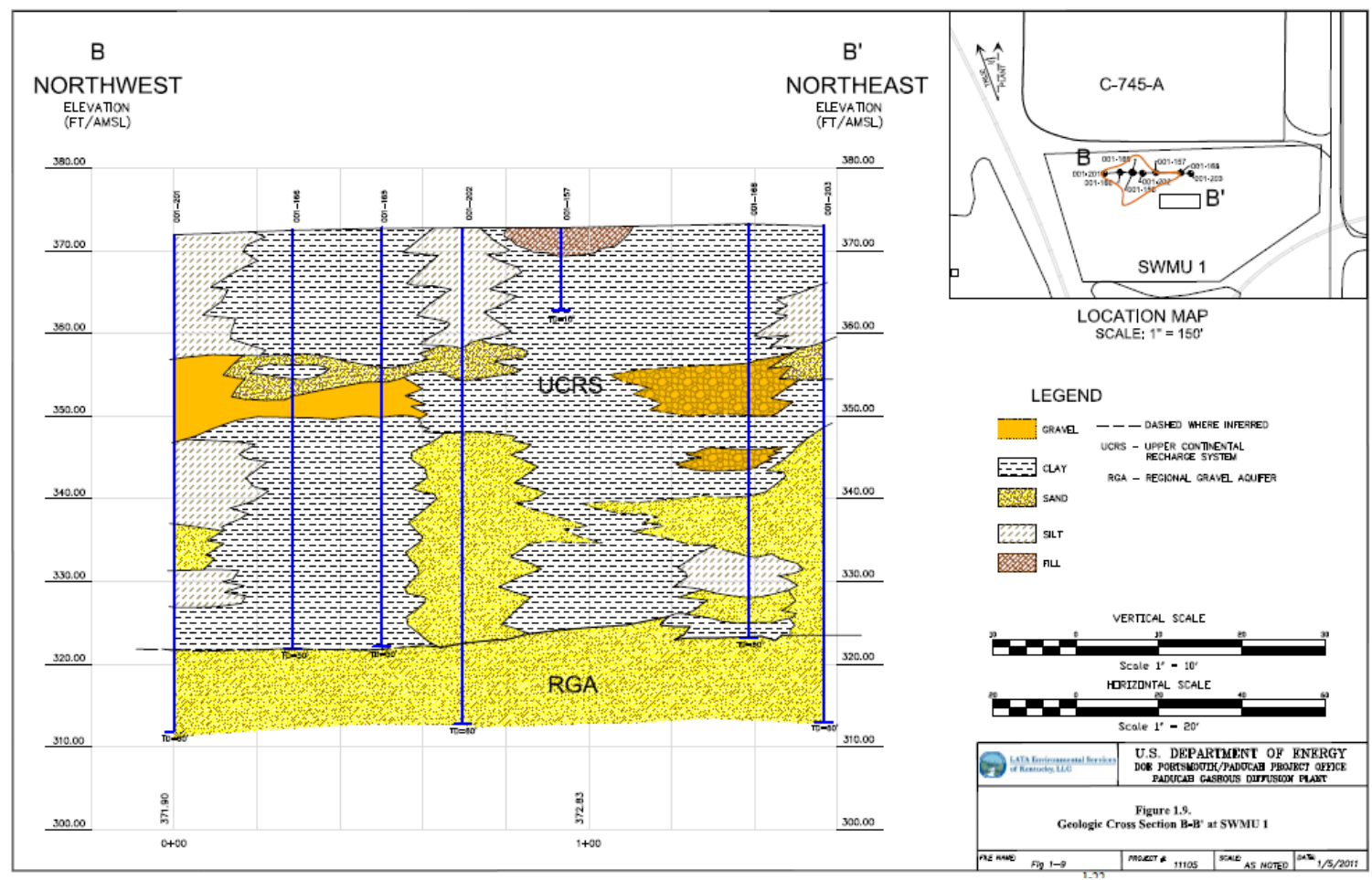

Figure 5. Interpreted lithostratigraphy for the Oil Landfarm (SWMU 1) from the SW Plume Area FFS

The ITR suggests that the site-specific lithologic structure, a heterogeneous fine-grained zone overlying a coarse-grained aquifer, is a key (and controlling) feature of this site. Further, the ITR suggests that the location, geometry, and character of sand lenses in the UCRS and the location, geometry, and character of the UCRS/RGA interface are features that assist in optimizing and focusing treatment.

The opportunity to beneficially utilize this subsurface structure and contaminant geometry is somewhat reduced by the FFS interpreted contaminant distribution that was projected from the soil/sediment characterization data (Figure 6). Note that the contaminants are contoured somewhat isotropically (i.e., with minimal fidelity to the lithostratigraphy). An alternative presentation of the data (Figure 7) provides more insight into the contaminant distribution (location, and geologic controls). In this form, it is relatively clear that the most contaminated materials are associated with high permeability zones in the UCRS. Further, these zones are significantly above the piezometric surface of the RGA - suggesting the potential viability of SVE (following limited water removal as needed). 


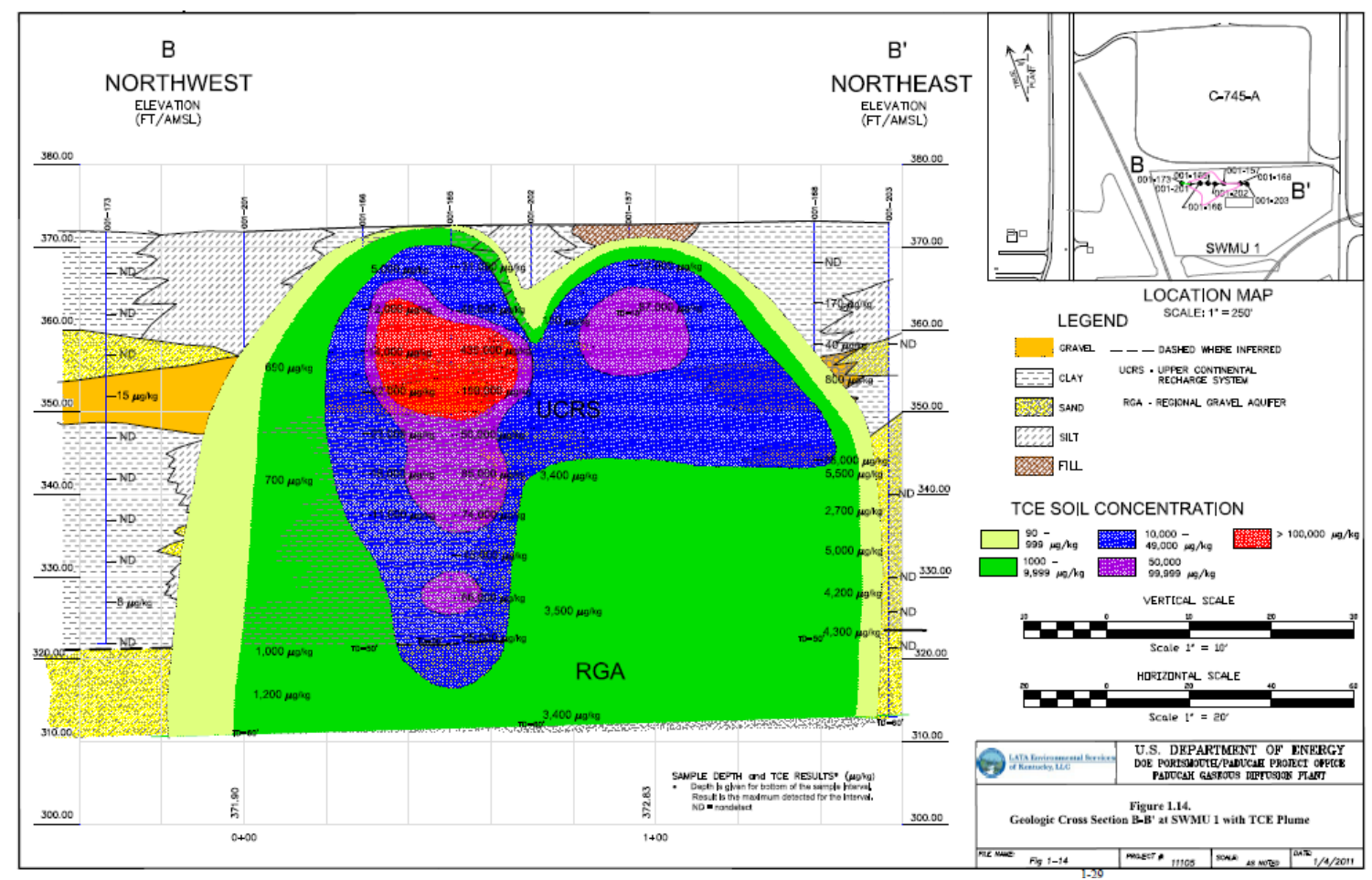

Figure 6. Interpreted contaminant cross section for the Oil Landfarm (SWMU 1) from the SW Plume Area FFS

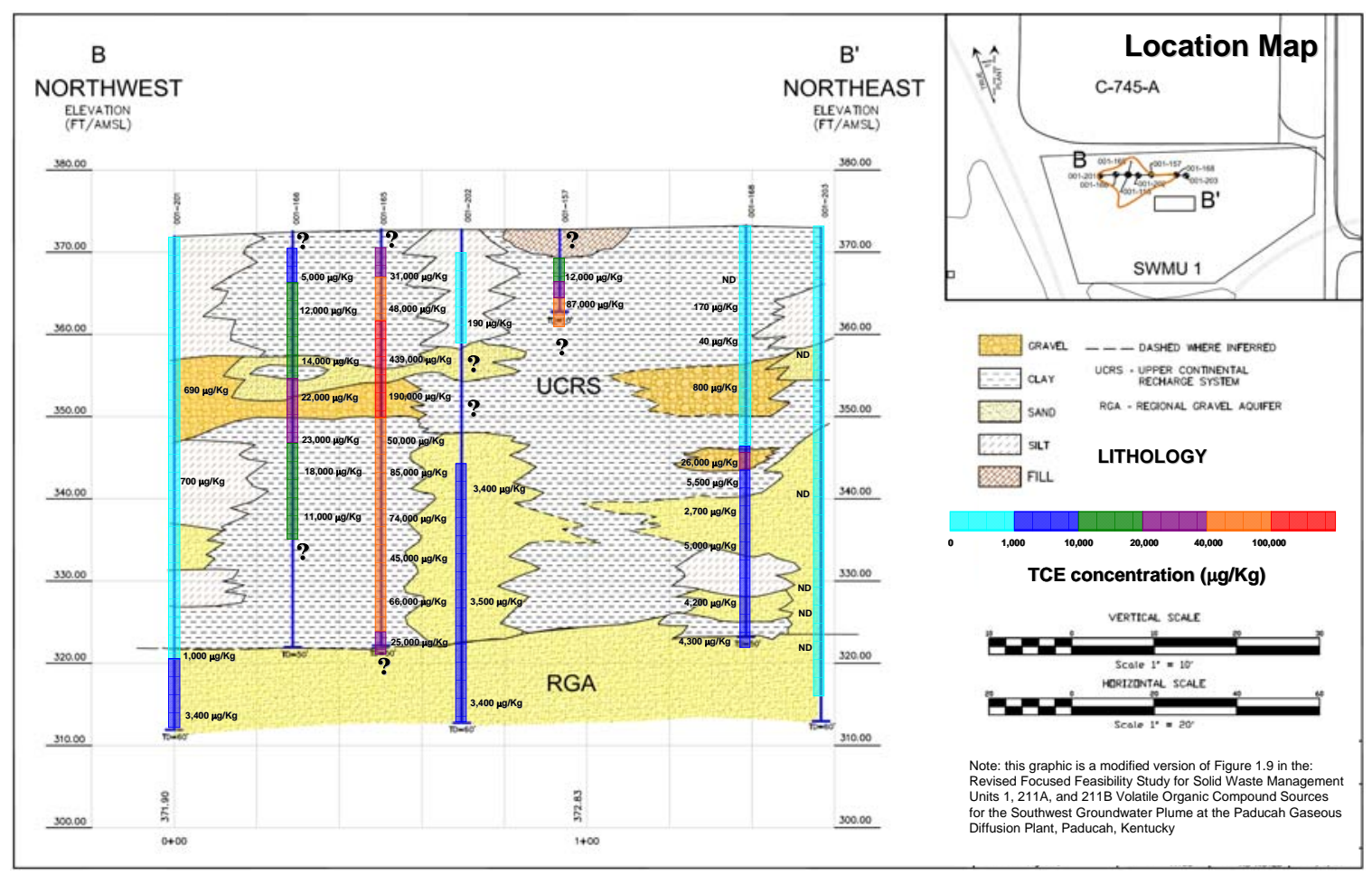

Figure 7. Alternative contaminant cross section for the Oil Landfarm (SWMU 1) from the SW Plume Area FFS 
This simple concept is further developed in Figure 8. This figure overlays several areas of opportunity that can be considered for standard or innovative treatment options. Several targets have been highlighted to illustrate some, but not all, of the areas that could be selected for targeted treatments or pilot tests. Area 1 is a high permeability zone with very high concentrations of contaminants just below a low permeability zone with even higher concentrations of contaminants. This area in the vadose zone could be used in a variety of ways including: a) SVE, b) as a focused injection point receiving oxidants or reductants, c) as an area for deep soil mixing and blending of reagents, or d) as an extraction point for localized heating. Area 2 is below the water table and represents a "sharp" interface between an upper fine-grained UCRS and the more permeable RGA. This area could be used to deploy amendments that would form a barrier treatment and/or partitioning zone. An example might entail the injection of buoyant liquid carbon substrate (e.g., vegetable oil) or the sequential injections of zero valent iron (ZVI) and low-density liquid carbon. Area 3 is a high permeability vertical column bridging the saturated and unsaturated zones. This area appears to be a natural funnel that may be used as a treatment zone by: a) SVE or b) filling or partially filling with amendment. One could envision the development or injection of an amendment gas in this area that could diffuse into the lower permeability, more highly contaminated areas around it. Area 4 is a localized high permeability zone with relatively high contaminant concentrations (this zone may be connected with the other contaminated high permeability zones out of the plane of the cross section). This area could be specifically targeted for treatment similar to Area 1 . Area 5 is poorly characterized but may be a target for a) oxidant candle technology (EPA, 2011, or a similar granular oxidant diffusion borehole deployment), b) multiple, closely spaced injections of amendment, or c) deep soil mixing and blending of reagents. It is important to bear in mind that this list is not comprehensive and should only be used as a starting point for examining and matching geologic/contaminant distribution occurrences (opportunities) with remediation performance and deployment characteristics.

In the following sections, two example technologies - SVE Lite and Focused Bioremediation - are discussed in more detail. Note that these technology classes were both included in the FFS, but the ITR believes that a more efficient and potentially effective deployment is possible. In both cases, a smaller and more focused remediation is envisioned. The SVE is potentially applicable to the Oil Landfarm (SWMU 1), but is of particular interest for the C-720 spill sites (SWMU 211A/211B) - sites that the PP identified long-term monitoring and LUCs as the preferred option. The ITR believes that in cases where a minimal action alternative, such as LUCs, is potentially acceptable, there is little basis for implementing a robust and expensive exemplar of a technology class (e.g., multiphase extraction) as the comparison technology in a FFS and PP. Instead, a more modest exemplar (e.g., SVE) may be more appropriate -- providing an additional level of performance for a significantly lower cost. 
SRNL-STI-2011-00290

Page 18 of 46

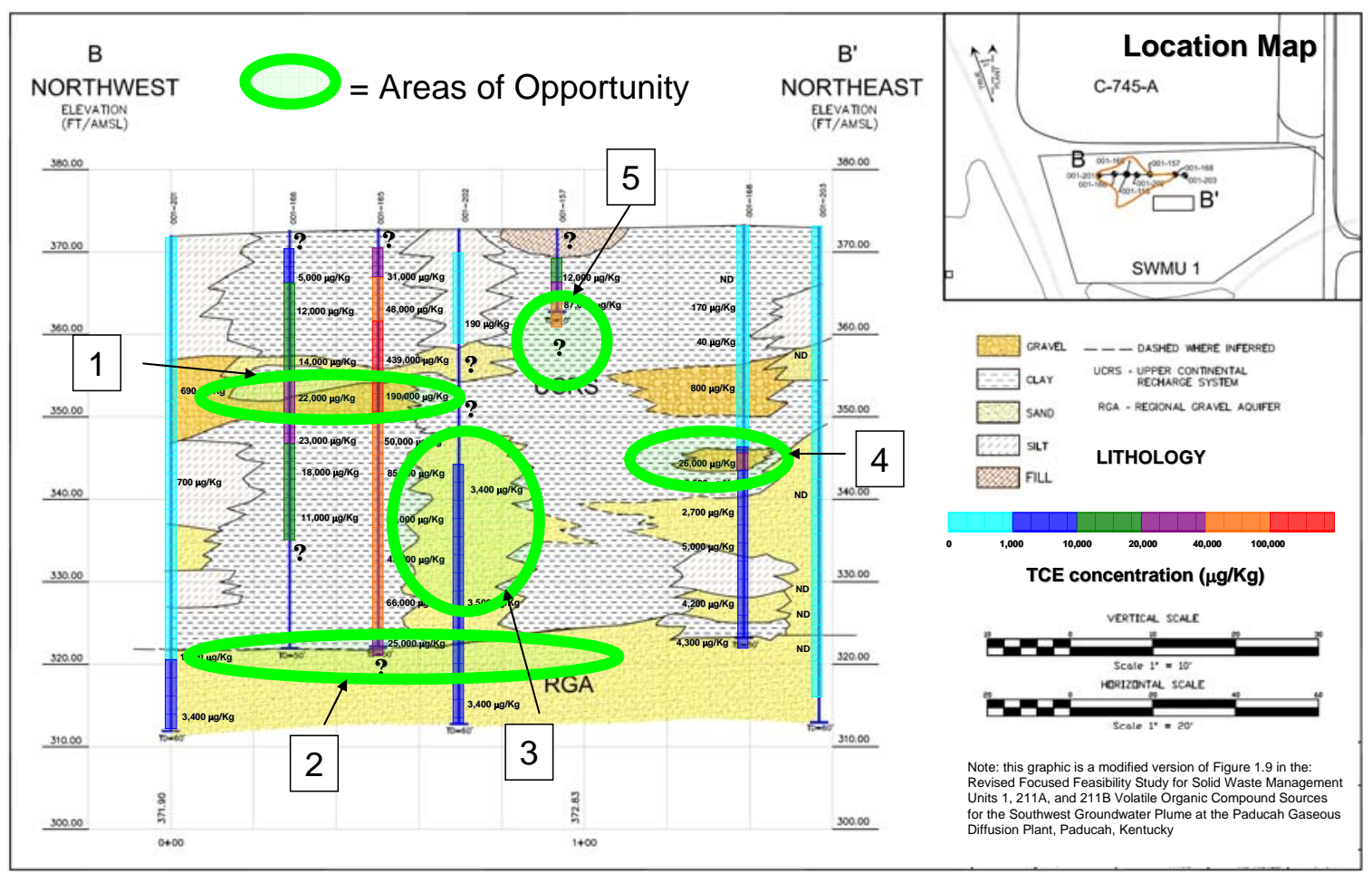

Figure 8. Lithostratigraphic areas of opportunity for the Oil Landfarm (SWMU 1) 


\section{Soil Vapor Extraction - "SVE Lite”}

A detailed analysis (Appendix C) describes a low-cost soil vapor extraction option - SVE Lite. The evaluation suggests that the idea is potentially reasonable for both the Oil Landfarm (SWMU 1) and then for the C-720 spill sites (SWMU 211A/211B). In performing the work, the ITR replicated the source estimate in the SI reports and FFS and then applied standard models to estimate required flow rates and treatment timeframes. In both cases a relatively small system emerged from the analysis. An example photograph of such a system is presented in Figure 9. Note that the addition of offgas treatment and the potential need for performing some water removal (a period of initial removal followed by $<5$ gallons per hour nominal steady state removal to balance percolation) would increase the required equipment and associated costs, but final system costs should be relatively low. As with any potential technology, an adequate pilot or field test is recommended to determine the permeability of the vadose zone and refine estimates of the mass removal rates and projected timeframes. The "full-scale" system response to such testing (or to remedial system startup activities) is often the most effective and diagnostic information that can be collected from a site.

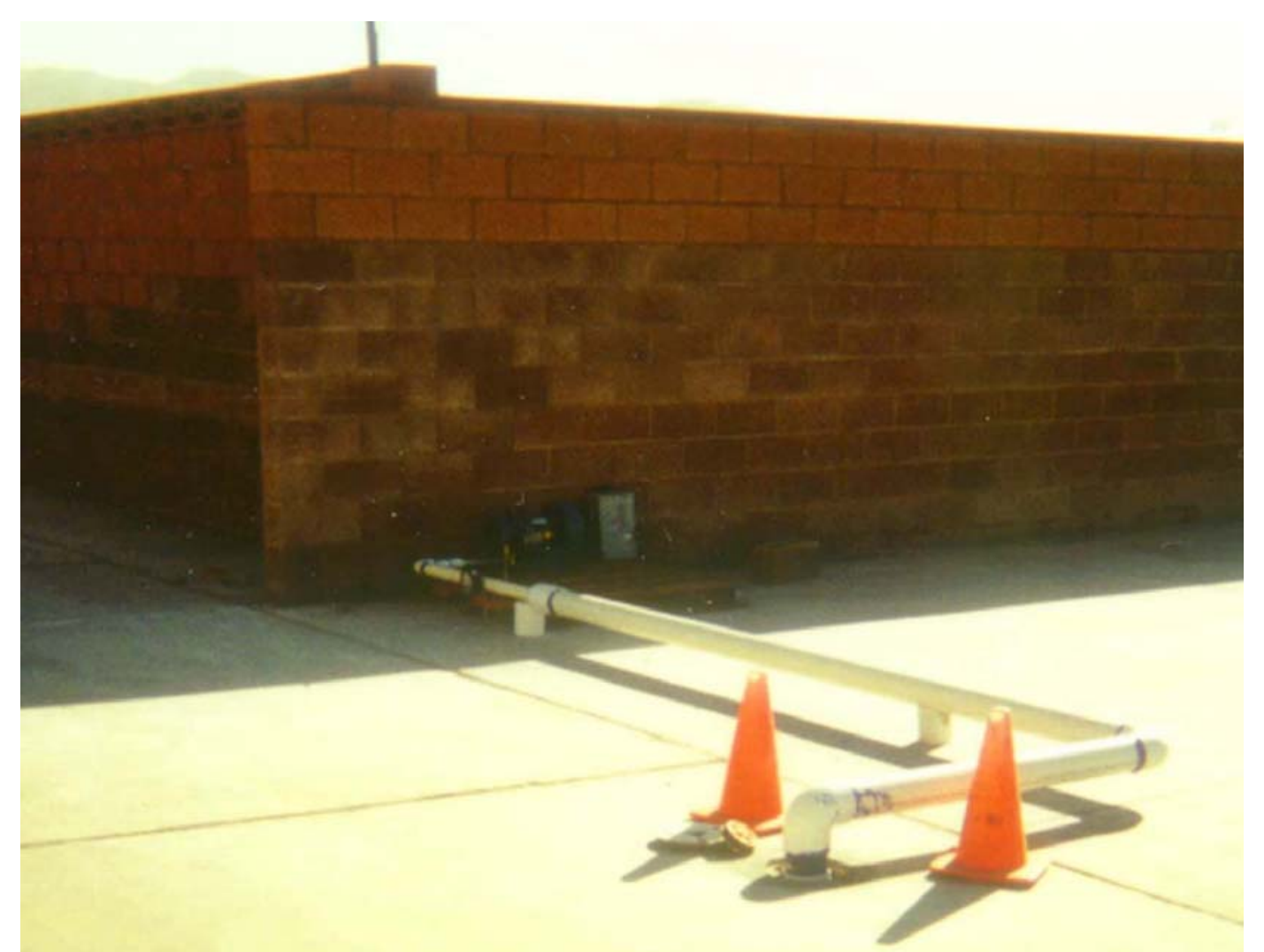

Figure 9. Photograph of a SVE System Operating at $60 \mathrm{scfm}$ without Vapor Treatment 


\section{Evaluation of SVE Lite for the Oil Landfarm (SWMU 1) Source Term in the UCRS}

The preferred remedy for the UCRS at the Oil Landfarm (SWMU 1) as described in the FFS is, Alternative 8-In Situ Source Treatment Using Enhanced In Situ Bioremediation with Interim Land Use Controls. This remedy involves the installation of deep gravity feed wells along with a shallow infiltration gallery for the system. A bioamendment composed of microbes, nutrients, and/or reductants, as necessary, would be injected or placed in the wells and gallery to allow the amendment to enter the subsurface either by gravity or under pressure. However, the site is assumed to have a relatively low permeability and therefore a high probability exists that the zigzag trench will provide minimal seepage and that infiltrating water and amendments will travel through preferential flow paths and lack adequate contact with the TCE for an efficient delivery.

SVE was considered as part of two alternatives in the focused feasibility study: Alternative 5: In Situ Thermal Treatment with Interim LUCs and Alternative 7: In Situ Soil Flushing and Source Treatment Using Multiphase Extraction with Interim LUCs. Yet, SVE alone was not adequately considered for the TCE source in the UCRS. Evaluation of SVE was abandoned presumably because the source was in the shallow vadose zone and the technical constraints of constructing a surface barrier to impede surface flow at an industrial setting (DOE 2011a). Note that the site has a substantial natural cap comprising low permeability sediments (Figure 8) and significant natural anisotropy so that an additional barrier is not necessary. Moreover, for SVE, the presence of high permeability layers beneath this natural barrier (e.g., Figure 8, areas 1 and 4) will assist in developing a broad zone of influence and maximize effectiveness.

The ITR utilized the model of SVE presented in the Army Corps of Engineers, Soil Vapor Extraction and Bioventing, Engineers Manual EM-1110-1-4001 (2002), "Appendix F, Overview of Rebound Test Procedures and Data Evaluation" to evaluate the potential impact of SVE at the Oil Landfarm (SWMU 1). Appendix F is attached. This model conceptualizes the vadose zone as having two regions: mobile (i.e., coarsegrained soils) and immobile (i.e., fine-grained soils). The model assumes vapor flows through the coarse soil and that contaminant must be transported by diffusion or pore water advection from fine grained units prior to extraction (i.e., the classic mass transfer constraints for SVE). This two-region model has been applied at many sites - these past applications along with the data from the SI reports provide realistic estimates for the application to the Oil Landfarm (SWMU 1).

All of the assumed parameters and model results are provided in Appendix C. An example model output is provided in Figure 10. This figure projects the mass in the site using a modest SVE Lite system, assuming an extraction rate of 60 standard cubic feet per minute (scfm) that can be achieved using a 1.5-horsepower regenerative blower operating at a vacuum of 50 inches of water powered with about 1,500 watts of energy from a standard, single-phase, 20-amp circuit. Figure 10 demonstrates that the permeable zone is swept rapidly and then mass transfer constraints limit the mass extraction rate. For the rough estimates of this review, the model suggests nearly $90 \%$ of the source TCE mass in the UCRS at the Oil Landfarm (SMWU 1) could be extracted in about 7 months 
of SVE at the low flow rate of $60 \mathrm{scfm}$. Monitoring of the system during startup would help reduce uncertainties and allow a more precise estimate of timeframe.

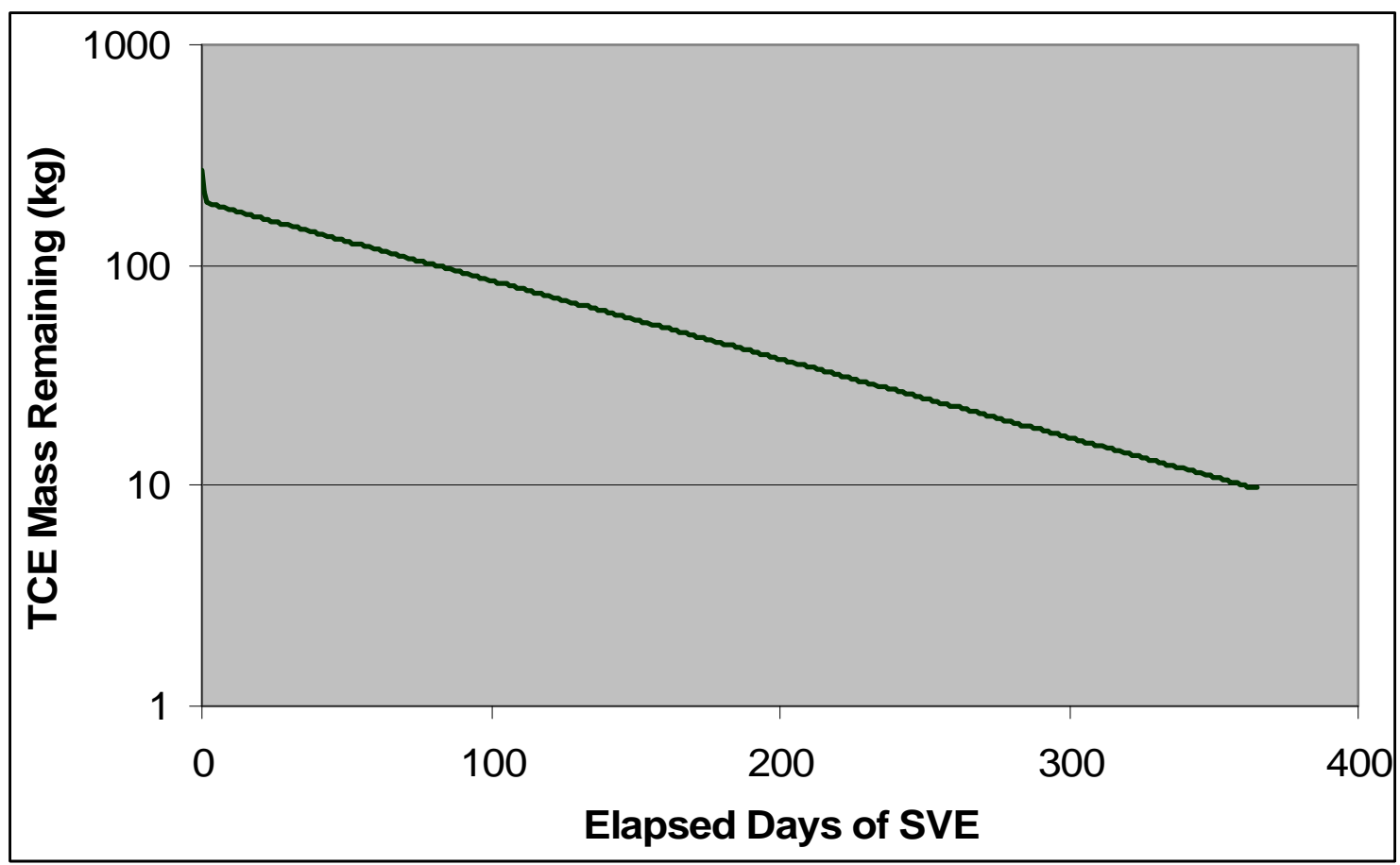

Figure 11. Modeled TCE Mass Remaining in the UCRS at SWMU 1 during SVE Lite

As noted above, the similarly sized system pictured in Figure 10 did not require vapor treatment. For the mass of TCE estimated at the Oil Landfarm (SWMU 1), an appropriate vapor treatment technology would be activated carbon in 2,000-pound vessels. For a total TCE mass of $273 \mathrm{~kg}$ (600 pounds), the total activated carbon requirement would be about 5,000 pounds. Hence, a pair of 2,000-pound vessels should be deployed. After breakthrough in the front vessel, it would be sent off-site for treatment and a new vessel placed in line. The total activated carbon requirement, assuming the mass estimate is accurate, would be about 6,000 pounds. The total cost of this carbon including purchase, disposal and rental of the vessels would be about $\$ 30,000$, and would constitute the bulk of the capital cost of the system. A small regenerative blower with simple control panel can be purchased (equipment cost) for less than $\$ 10,000$. The model indicates that the extraction could be performed in a single well (or by using a limited number of wells to produce the required flow). Based on the data in the SI reports, the system would also require the ability to remove and or handle modest amounts of water from the targeted UCRS zone. An automated system with a knock out pot, small dewatering pump, and the associated equipment costs would require an additional $\$ 10,000$ to $\$ 50,000$. Disposal costs for the initial dewatering fluids and a "steady state" water generation rate of less than approximately 5 gallon per hour would need to be factored into the operations costs). Engineering and operation of this system would be relatively simple and straightforward. 
The analysis for these sources (see Appendix C) is similar to the analysis described above. The preferred remedy for the UCRS at Building C-720 (SWMU 211A/211B) as described in the FFS is, Alternative 2-Long-Term Monitoring with Interim Land Use Controls. This remedy involves primarily monitoring at the site and access controls. Similar to the alternatives for the Oil Landfarm (SWMU 1), SVE alone was not adequately considered for the TCE source in the UCRS. For the rough estimate assumed for this review, the model suggests nearly $90 \%$ of the source TCE mass in the UCRS at Building C-720 (SWMU 211A/211B) could be extracted in about 6 months of SVE at the low flow rate of $60 \mathrm{scfm}$.

For the mass of TCE estimated at Building C-720 (SWMU 211A/211B), the appropriate vapor treatment technology would be activated carbon in 2,000-pound vessels. For a total TCE mass of $111 \mathrm{~kg}$ (245 pounds), the total activated carbon requirement would be about 2,000 pounds. Hence, a pair of 2,000-pound vessels should be deployed.

Theoretically, the site would be effectively remediated at the point of breakthrough in the front vessel. Both vessels would be sent off-site for treatment and disposal. The total activated carbon requirement, assuming the mass estimate is accurate, would be about 4,000 pounds. Costs for SVE Lite applied to the Building C-720 spill sites (SWMU 211A/211B) would be similar to the costs for application to Oil Landfarm (SWMU 1).

\section{Interface Focused Remediation}

The slow release from at the interface between the UCRS and the RGA provides a unique opportunity to remediate or reduce the flux of contaminants entering the fast flowing RGA. The SI data suggest that, at this time, the principal reservoir feeding contamination to the RGA is located in fine-grained materials in the UCRS. The interface between fineand coarse-grained materials may facilitate the deposition of a reactive or barrier zone in the horizontal plane. Potential injections of amendments such as vegetable oil or ethyl lactate or a similar bioremediation agent with partitioning properties, as well as fine mesh ZVI or other amendments are potentially viable. Injections of amendments that are less dense than water may allow better, more continuous lateral distribution of the amendments as the amendment floats to the interface where it will tend to spread and provide better coverage. These amendments can be selected to provide a treatment zone and a barrier between the contaminants in the fine grain materials and the fast flowing coarse-grained zones.

One realization of this strategy may potentially involve injections of ZVI just below the fine/coarse-grained interface followed by injections of a low density liquid (like oil or other compounds or mixtures) below the ZVI (Figure 12). The ZVI will provide a permeable reactive zone for chlorinated contaminants to be chemically reduced as they migrate down. The ZVI will also produce hydrogen gas and will enhance the production of methane gas; both of these gases will rise up and laterally along the fine grain zone interface, promoting biological reduction. Supplemental injection of a buoyant, low density liquid below the ZVI will seal the reducing zone created by the ZVI and 
hydrogen and insulate the reduction zone and hydrogen from the fast flowing oxygenated water in the coarse zone. Of course, the low density liquid may also serve as carbon substrate for additional biological activity as well and a partitioning barrier. To our knowledge, this technique has not yet been intentionally implemented at a site, and will require pilot scale testing to verify performance.

\section{Example costs for injection for the Oil Landfarm (SWMU 1)}

Assumptions

- Treatment area of approximately 4,000 square feet at a depth of approximately 50 feet. Target thickness of approximately 5 feet - total treatment volume is approximately 20,000 cubic feet $\sim 1,100$ tons.

- Effective porosity is 0.25 - total effective pore volume is approximately 5,000 cu feet $\sim 37,400$ gallons.

- The radius of influence of each injection point is approximately 8'- 20 injection points are required for the area.

- Inject amendment at $0.5 \mathrm{wt} \%$ of total target mass (11,000 lbs).

Heuristic Values

- Inject between $5 \%$ and $10 \%$ of the total effective pore volume.

- Reductive amendment costs range between $\$ 2$ and $\$ 10$ per lb

- Ability to direct-push an average of approximately 200 vertical feet per day per rig.

- Ability to generally inject between 500 gallons to 2,500 gallons per day per crew.

- Injection crews have a commercial daily rate between $\$ 3,000$ and \$6,000 per day.

- DOE and other nuclear and high scrutiny sites generally incur contractor costs that are $5 \mathrm{x}$ average commercial sites because of site specific requirements/orders and additional site specific training.

From the assumptions about the site and the heuristic values, approximately 3,500 gallons of amendment solution/slurry will be injected, and it will take approximately 5 days to complete the injections. Based on these assumptions, the ITR projects remediation contractor costs in the range of $\$ 75,000$ and $\$ 150,000$ to complete the injections, and between $\$ 22,000$ and $\$ 110,000$ for the chemical amendments. 


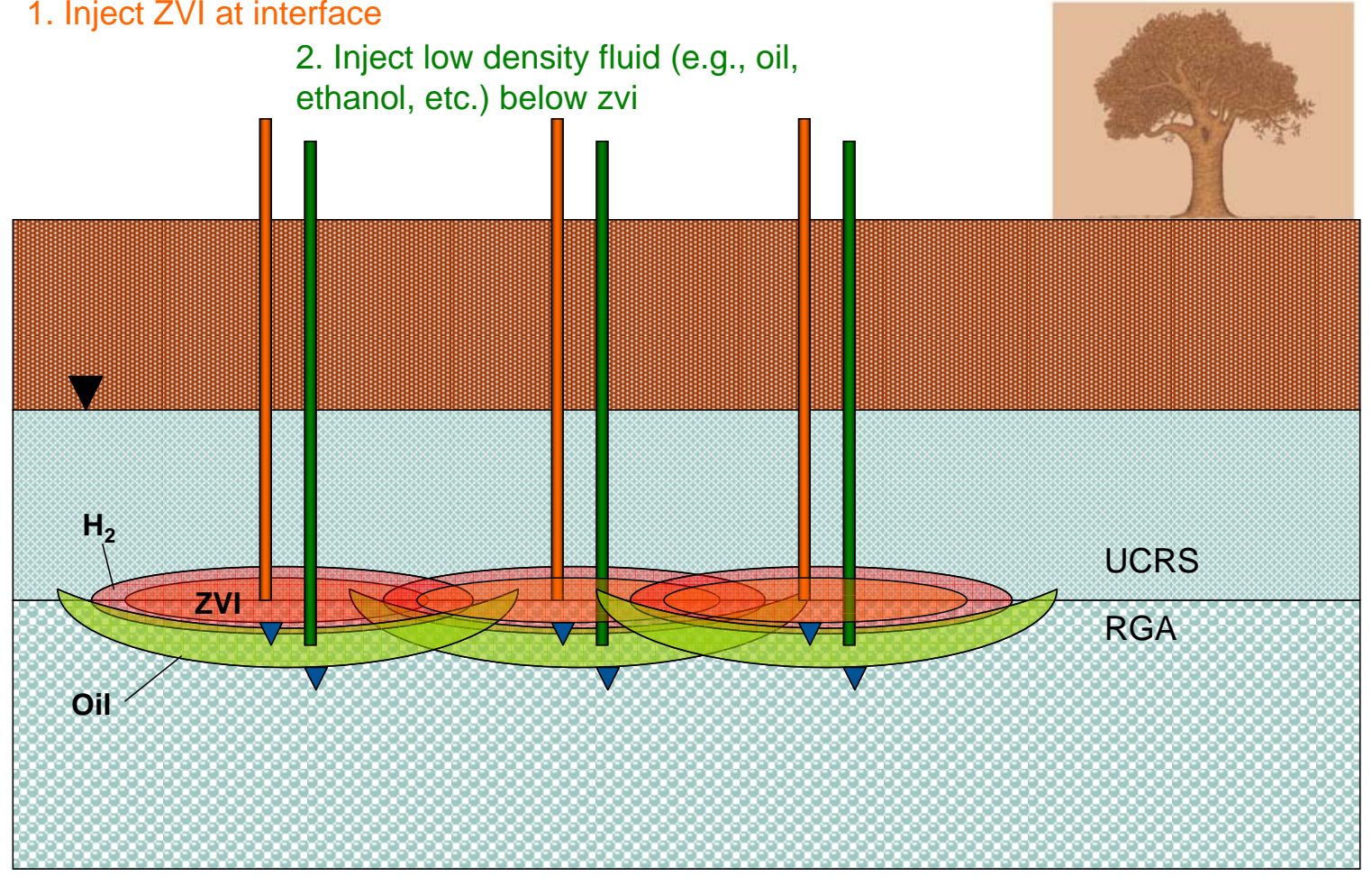

Figure 12. Simplified schematic diagram of UCRS/RGA Interface targeted remediation

An alternative to the injection of a reducing agent at the interface between the UCRS and the RGA is the injection of persistent oxidizing amendments at this interface. For example, the injection of supersaturated solutions of potassium permanganate has been implemented at several sites resulting in the precipitation of permanganate in the subsurface. The solid permanganate will slowly dissolve in the groundwater and maintain oxidizing treatment conditions. This strategy will work best in areas where groundwater flow is slow. In areas with fast flowing groundwater, dissolution of solid permanganate will be fast and may not be persistent enough to successfully treat a long term flux of contaminants.

\subsection{Conclusions}

The ITR commends DOE and their contractors for their efforts in characterizing and evaluating the multiple source areas in the SW plume at PGDP. The central recommendation of the team is that PGDP should consider technologies that are better matched to the concentration and hydrogeologic conditions for the target sites. While the preferred technologies identified in the PP are defensible, the ITR specifically recommends consideration of a scaled back SVE Lite for all three of the subject sources (the Oil Landfarm (SWMU 1) and the two C-720 spill sites (SWMU 211A/211B)) and consider a more focused bioremediation for the Oil Landfarm (SWMU 1). 


\subsection{References}

CH2M Hill 1992. Results of the Site Investigations, Phase II, Paducah Gaseous Diffusion Plant, Paducah, Kentucky. KY/Sub/13B-97777C P03/1991/1.

DOE 2001a. Remedial Investigation Report for Waste Area Grouping 3 at the Paducah Gaseous Diffusion Plant, Paducah, Kentucky. DOE/OR/07-1895/V1-V4\&D1, U.S. Department of Energy, Paducah, KY, September.

DOE 2001b. Data Report for the Sitewide Remedial Evaluation for Source Areas Contributing to Off-Site Groundwater Contamination at the Paducah Gaseous Diffusion Plant, Paducah, Kentucky, DOE/OR/07-1845\&D1, U.S. Department of Energy, Paducah, $\mathrm{KY}$.

DOE, 2007. Site Investigation Report for the Southwest Groundwater Plume at the Paducah Gaseous Diffusion Plant, Paducah, Kentucky, Report No. DOE/OR/072180\&D2/R1, June 2007, US Department of Energy, Paducah Portsmouth Project Office, Lexington KY.

DOE, 2008. 2005 End State Vision Annual Update for PGDP, DOE/OR/072119\&D2/R3, US Department of Energy, Paducah Portsmouth Project Office, Lexington KY.

DOE 2009a. Paducah CAB Briefing Southwest Plume June 2009. US Department of Energy, Paducah Portsmouth Project Office, Lexington KY.

DOE 2009b. Remedial Investigation Report for the Burial Grounds Operable Unit at Paducah Gaseous Diffusion Plant, Paducah, Kentucky. Redline Revision 1.

DOE/LX/0030\&D1/R1. US Department of Energy, Paducah Portsmouth Project Office, Lexington KY.

DOE 2010a. Burial Grounds Operable Unit Feasibility Study - D1 CAB Subcommittee Briefing May 2010. US Department of Energy, Paducah Portsmouth Project Office, Lexington $\mathrm{KY}$.

DOE 2010b. Engineering Evaluation/Cost Analysis for a Removal Action at the C-747 Contaminated Burial Yard and C-748-B Burial Area (SWMU 4) at the Paducah Gaseous Diffusion Plant, Paducah, Kentucky. DOE/LX/07-0335\&D1. US Department of Energy, Paducah Portsmouth Project Office, Lexington KY. .

DOE 2010c. Feasibility Study for the Burial Grounds Operable Unit at the Paducah Gaseous Diffusion Plant, Paducah, Kentucky. DOE/LX/07-0130\&D1. US Department of Energy, Paducah Portsmouth Project Office, Lexington KY. 
DOE 2010d. Remediation Project Cleanup Presentation for Paducah CAB October 2010. US Department of Energy, Paducah Portsmouth Project Office, Lexington KY.

DOE 2010e. Site Management Plan Paducah Gaseous Diffusion Plant Paducah, Kentucky Annual Revision - FY 2011. DOE/LX/07-0348\&D1. US Department of Energy, Paducah Portsmouth Project Office, Lexington KY.

DOE 2010f. Remedial Investigation Report for the Burial Grounds Operable Unit at the Paducah Gaseous Diffusion Plant, Paducah, Kentucky, DOE/LX/07-0030\&D2/R1, U.S. Department of Energy, Paducah, KY, February.

DOE, 2011a. Revised Focused Feasibility Study for Solid Waste Management Units 1, 211A, and 211B Volatile Organic Compound Sources for the Southwest Groundwater Plume at the Paducah Gaseous Diffusion Plant, Paducah, Kentucky, Report No. DOE/LX/07-0362\&D1 January 2011, US Department of Energy, Paducah Portsmouth Project Office, Lexington KY.

DOE 2011b. Revised Proposed Plan for Solid Waste Management Units 1, 211A, 211B, and Part of 102 Volatile Organic Compound Sources for the Southwest Groundwater Plume at the Paducah Gaseous Diffusion Plant, Paducah, Kentucky. DOE/LX/070363\&D1. US Department of Energy, Paducah Portsmouth Project Office, Lexington KY.

EPA, 2011. ERI Survey Helps Delineate TCE Plume and Guide Field Testing of Innovative ISCO Candle Technology. EPA Technology News and Trends, US Envionmental Protection Agency Technology Innovation and Field Services Division Clean Up Information (CLU-IN) Program, Washington DC, March 2011. Available at: http://cluin.org/products/newsltrs/tnandt/view.cfm?issue=0311.cfm

Government Accounting Office (GAO) 2003. Nuclear Waste Cleanup Preliminary Observations on DOE's Cleanup of the Paducah Uranium Enrichment Plant. GA0-04278T.

Looney, B., J. Costanza, E. Davis, J. Rossabi, L. Stewart, and H. Stroo, 2007. Review Report: Building C-400 Thermal Treatment 90\% Remedial Design Report and Site Investigation, PGDP, Paducah Kentucky, WSRC-STI-2007-00427, U.S. Department of Energy Office of Scientific and Technical Information, Oak Ridge TN, publically available through www.osti.gov .

Paducah Remediation Services (PMS) 2009. Trichloroethene and Technetium-99 Groundwater Contamination in the Regional Gravel Aquifer for Calendar Year 2007 at the Paducah Gaseous Diffusion Plant Paducah, Kentucky. PRS/PROJ/0046/R1. Department of Energy, Paducah Gaseous Diffusion Plant, Paducah, Kentucky. 
Appendix A.

Independent Technical Review Team

Statement of Work 


\section{STATEMENT OF WORK}

For Review of the revised Focused Feasibility Study and Proposed Plan for Solid Waste Management Units 1, 211A, 211B, and Part of 102 Volatile Organic Compound Sources for the Southwest Groundwater Plume at the Paducah Gaseous Diffusion Plant, Paducah, Kentucky,

\section{PURPOSE:}

The U. S. Department of Energy (DOE) is currently developing a proposed plan (PP) for remediation of sources to the Southwest Groundwater Plume, which consists of groundwater in the Regional Gravel Aquifer (RGA), contaminated primarily with TCE, a volatile organic compound (VOC). This plume is located within the DOE property, west of the C-400 Building, and south of the larger groundwater contamination area identified as the Northwest Groundwater Plume. The PP presents the Preferred Alternatives for remediation of VOCs in the Upper Continental Recharge System (UCRS) subsurface soils at Solid Waste Management Unit (SWMU) 1, Oil Landfarm, and the C-720 Building TCE Northeast Spill Site and Southeast Spill Site (SWMU 211A and 211B). These sites are sources of contamination to the Southwest Plume.

The basis for this decision is documented in the "Revised Focused Feasibility Study for Solid Waste Management Units 1, 211A, and 211B Volatile Organic Compound Sources for the Southwest Groundwater Plume at the Paducah Gaseous Diffusion Plant, Paducah, Kentucky,” DOE/LX/07-0362\&D1, dated January 2011 (hereafter referred to as the Revised FFS) and the "Site Investigation Report for the Southwest Groundwater Plume at the Paducah Gaseous Diffusion Plant, Paducah, Kentucky,” DOE/OR/07-2180\&D2/R1, dated June 2007 [hereafter referred to as the Site Investigation (SI) Report]. The Site Investigation determined that the storm sewer [part of SWMU 102 leading from the C-400 Building to Outfall 008 (Figure 2)], which was also included in the investigation, was not a source of groundwater contamination and, therefore, no further action is proposed for that area.

\section{SCOPE:}

The selected team of experts will receive electronically, for their information, background materials concerning the Southwest Groundwater Plume sources being addressed as part of this action. After considering background material, the team will meet with site personnel via video or phone conference, to discuss issues or obtain additional information necessary to complete the review of the Revised FFS and the PP. At the close of the review period, the team will brief DOE and contractor staff on the results of their review. Subsequently, the team will provide a report consisting of a written set of comments. This report will be provided to the contactor at the Paducah site for response and revision of the Revised FFS and/or PP. After consideration of comments and preparation of responses, the team will participate in a comment resolution meeting.

The team of experts is expected to apply their expertise in, and prior experience with, groundwater remediation technologies to help DOE identify issues that are affecting or could affect the successful implementation of a selected remedy. In addition, the team is expected to make recommendations that would result in cost-effective resolution of identified issues. 


\section{TIME AND COST ELEMENTS}

1. Review of background materials (estimated 20 hours per team member)

2. Video/Teleconference to discuss issues and brief DOE on initial comments Deliverable \#1 (8 hours per team member, including preparation time)

3. Review of Revised FFS and PP and preparation of comment report (estimated 24 hours per team member)

4. Deliverable \#2 - Comments Report (10 to 15 pages maximum; estimated 10 hours per team member)

5. Video/Teleconference for comment resolution - Deliverable \#3 (8 hours per team member, including preparation time)

6. Follow-up discussions with contractor and DOE staff (estimated 10 hours per team member) 


\section{Appendix B \\ ITR Team Members \\ Dr. Brian Looney (technical lead), Savannah River National Laboratory Dr. Joseph Rossabi, Redox-Tech, LLC \\ Dr. Lloyd (Bo) Stewart, Praxis Environmental, Inc. Short Curriculum Vitae Attached}


SRNL-STI-2011-00290

Page 31 of 46

Brian B. Looney

Savannah River National Laboratory, Building 773-42A, Aiken SC

phone: (803) 7253692 or (803) 7252418 (work); (803) 6487784 (home)

fax: (803) 7257673

email: brian02.looney@srnl.doe.gov (work); sclooneyy@yahoo.com (home)

\section{Summary Information}

Dr. Brian B. Looney is a senior fellow engineer at the Department of Energy Savannah River National Laboratory (SRNL) in Aiken SC and an adjunct professor in the Environmental Engineering Science Department at Clemson University. Dr. Looney coordinates development and deployment of innovative environmental characterization and clean-up methods at the Savannah River Site, and serves as a technical advisor supporting the DOE Environmental Management Program.

\section{Education:}

1984 Ph.D. Environmental Engineering, University of Minnesota

1978 B.S. Environmental Science, Texas Christian University

\section{Selected Research Projects:}

2005-2007 Interstate Regulatory and Technology Council (Technical Support to Enhanced Attenuation Team)

2003-2007 Monitored Natural Attenuation and Enhanced Attenuation of Chlorinated Organics

(PI)

2003 Aqueous treatment of mercury using chemical reduction and air stripping (PI)

1992-1996 Development of gas phase phosphorus amendment for enhanced bioremediation (PI)

1989-1992 In situ enhanced cometaboloic treatment of TCE using natural gas (PI)

1987-1989 In situ air stripping using horizontal wells (PI)

1986 DOE pilot testing of soil vapor extraction (PI)

\section{Patents:}

Brian holds nine patents related to environmental remediation and characterization. These include:

4,832,122 \& 5,263,795 - various applications of horizontal wells for remediation

$5,480,549 \& 5,753,109$ - various application of gas phase phosphorus to support bioremediation

$5,293,931 \& 5,339,694$ - multilevel sampling system and groundwater flow probe

$6,367,563$ \& 6,280,625 - DNAPL collection system and modified airlift recirculation with deep recharge

\section{Selected Awards:}

2006 Citizens for Nuclear Technology Awareness (CNTA) Fred C. Davison Distinguished

Scientist of the Year

2005 - National Groundwater Association Technology Award

2004 - American Chemical Society (ACS) Industrial Innovation Award

2004 - World's Best Technology Award

2000 - Energy 100 Award

1996 \& 2000 - Federal Laboratory Consortium Award for Excellence in Technology Transfer 1996 - George Westinghouse Signature Gold Award

1994 \& $1995-$ R\&D 100 Award

\section{Selected Professional Affiliations:}

American Chemical Society, National Groundwater Association, American Society of Civil Engineers, Association of

Applied Geochemists 
SRNL-STI-2011-00290

Page 32 of 46

\author{
Joseph Rossabi \\ Redox Tech, LLC \\ 200 Quade Drive \\ Cary, NC 27513 \\ 919-678-01407/Fax 919-678-0150 \\ E-mail: rossabi@redox-tech.com
}

\title{
Summary Information:
}

Joe Rossabi is principal scientist and part owner of Redox Tech, LLC where he applies innovative remediation solutions, including steam injection, chemical injection (for oxidation or reduction of contaminants), and metals stabilization, to soil and groundwater contamination. Prior to Redox Tech, he was a fellow engineer in the Environmental Sciences and Technology Division of the Department of Energy's Savannah River National Laboratory where he performed applied research and development of environmental characterization and remediation technologies and strategies. His research involved field-testing and implementation of cone penetrometer-based characterization and remediation methods, multiphase flow processes including DNAPL fate and transport, and passive and renewable energy powered methods for characterization and remediation of subsurface contaminants. Licensed Professional Engineer, South Carolina, North Carolina

\section{Education:}

Ph.D., Environmental Engineering and Science, Clemson University, 1999.

MS., Environmental Engineering, University of North Carolina, Chapel Hill, 1991.

MS., Physics, State University of New York, Binghamton, 1985.

BA., Physics, BA., Philosophy, State University of New York, Binghamton, 1982.

\section{Relevant Experience}

Partner: Redox Tech, LLC, Cary, North Carolina, 2004-Present. Chief of operations for soil and groundwater remediation firm specializing in in situ treatment. Redox Tech provides turnkey remediation services. Redox Tech has remediated more than 250 sites with contaminated soils and groundwater using both conventional and innovative technology strategies such as in situ oxidation and reduction with chemical and biological amendments (subsurface injection and blending), steam injection and other strategies.

Fellow Engineer: Environmental Sciences and Technology Department, Savannah River National Laboratory, Westinghouse Savannah River Company, Aiken, South Carolina, 1991-2004.

Research in the areas of subsurface flow, transport, characterization and remediation of contaminated sites. Development/field testing of innovative environmental characterization and monitoring technologies (particularly for DNAPL investigations and cone penetrometer tests). Research/implementation of barometric pumping for characterization, monitoring, and remediation. Teaching of characterization methods and DNAPL fate and transport. National technical review committees and assistance groups including Navy (Direct Push Wells), Paducah (Remedial technologies), Hanford (DNAPL technologies), Los Alamos (Passive Soil Vapor Extraction).

Member of Technical Staff: AT\&T Bell Laboratories; Quest Research Corporation, New Jersey, 1985-1990. Research in the areas of spectroscopic analysis of semiconductors, laser propagation/communications through the atmosphere, optical counter measures, and fiber optic spectroscopy techniques for chemical sensing. 
SRNL-STI-2011-00290

Page 33 of 46

\section{Licensure, Selected Awards, Patents, Affiliations}

SRTC Laboratory Director's Award (2003);

Westinghouse Savannah River Company President's Award (2003)

George Westinghouse Signature Award of Excellence -3 (1994, 2001); Innovation Award (1997, 1993)

Federal Laboratory Consortium Technology Transfer (1999); Government and Environmental

Sciences Company Innovations Award (1998)

B.G. Lamme Graduate Scholarship Award (1997)

US 6,971,820 - Renewable energy powered, assisted barometric valve.

US 5,641,245; CA 2,221,770; US 6,425,298; US 6,591,700 - Various applications for passive removal of subsurface contaminants.

US 5,775,424; US 5,922,950 - Various applications of multiple depth discrete sampling ports for installation in a single well.

US 5,889,217 - Cone penetrometer process and apparatus for obtaining samples of liquid and gas from soil at discrete depths.

US 6,367,563 - Method and Device for removing a non aqueous phase liquid from groundwater.

American Geophysical Union, National Groundwater Association, National Society of Professional Engineers, American Water Works Association, Duke University Cancer Protocol Committee

\section{Selected Publications:}

Rossabi, J., B. D. Riha, J. W. Haas III, C. A. Eddy-Dilek, A. G. Lustig Kreeger, M. Carrabba, W. K. Hyde, and J. Bello 2000. Field tests of a DNAPL characterization system using cone penetrometer-based Raman spectroscopy, Ground Water Monitoring and Remediation, 20 (4), pp 72-81.

Rossabi, J., R. W. Falta 2002. Analytical Solution For Subsurface Gas Flow To A Well Induced By Surface Pressure Fluctuations, Ground Water, 40 (1), pp 67-76.

Rossabi, J., Analyzing Barometric Pumping to Characterize Subsurface Permeability, in Part 2:

Measurement and Monitoring - Gas Transport in Porous Media, eds. C. K. Ho, S. W. Webb, pp 279-290, Springer, The Netherlands, 2006.

Rossabi, J., Subsurface Flow Measurements, in Part 2: Measurement and Monitoring - Gas Transport in Porous Media, eds. C. K. Ho, S. W. Webb, pp 291-302, Springer, The Netherlands, 2006.

Grimm, R.E., G.R. Olhoeft, K. McKinley, J. Rossabi, and B. D. Riha, Nonlinear Complex-Resistivity Survey for DNAPL at the Savannah River Site A-014 Outfall, Journal of Environmental and Engineering Geophysics,Vol 10 (4) pp. 351-364, 2005.

Rossabi, J., B. D. Riha, C. A. Eddy-Dilek, B. B. Looney, and W. K. Hyde, 2003. Recent Advances in Characterization of Vadose Zone Dense Non-Aqueous Phase Liquids (DNAPL) in Heterogeneous Media, Environmental \& Engineering Geoscience, 9 (1) pp. 25-36.

Rossabi, J., T. R. Jarosch, B. D. Riha, B. B. Looney, D. G. Jackson, C. A. Eddy-Dilek, R. S. Van Pelt, and B. E. Pemberton, Determining contaminant distribution and migration by integrating data from multiple cone penetrometer-based tools, in Proceedings of First International Conference on Site Characterization, (ISC '98), Atlanta, GA, Balkema Press, 1998.

Costanza, J., K.D. Pennell, J. Rossabi, and B. Riha. 2002. Effect of Temperature and Pressure on the MIP Sample Collection Process. In Proceedings of the Third International Conference, Remediation of Chlorinated and Recalcitrant Compounds, May 20-23, Monterey, CA.

Kram, M. L., A. A. Keller, J. Rossabi, and L. G. Everett, 2001. DNAPL Characterization Methods and Approaches: Part 1: Performance Comparisons, Ground Water Monitoring and Remediation, 21 (4). Kram, M. L., A. A. Keller, J. Rossabi, and L. G. Everett, 2001. DNAPL Characterization Methods and Approaches: Part 2: Cost Comparisons, Ground Water Monitoring and Remediation, 22 (1).

Rossabi, J., Barometric Pumping: Passive Soil Vapor Extraction, in Chapter 7: Remediation of Organic Chemicals in the Vadose Zone - Vadose Zone Science and Technology Solutions, eds. B. B. Looney, R. W. Falta, pp 970-979, Battelle Press, Columbus, OH, 2000.

Rossabi, J., Cone Penetrometer and Direct Push Tools for Vadose Zone Characterization, in Chapter 3: Vadose Zone Characterization and Monitoring - Vadose Zone Science and Technology Solutions, eds. B. B. Looney, R. W. Falta , pp 186-201, Battelle Press, Columbus, OH, 2000. 
Rossabi, J., Case Study of Cone Penetrometer (CPT)-Based Soil Moisture Probes, in Chapter 3: Vadose Zone Characterization and Monitoring - Vadose Zone Science and Technology Solutions, eds. B. B. Looney, R. W. Falta, pp 428-430, Battelle Press, Columbus, OH, 2000.

Rossabi, J. and R. W. Falta, The behavior of volatile organic contaminants in the vadose zone with respect to barometric pumping and the estimate of residual mass and mass removal using T2VOC, in Proceedings of TOUGH Workshop '98, Lawrence Berkeley National Laboratory, CA, 1998. Rossabi, J., and B. D. Riha, The Savannah River environmental technology field test platform, in Proceedings of the Instrument Society of America, New Orleans, LA, 1995.

Rossabi, J., B. B. Looney, C. A. Eddy-Dilek, B. D. Riha, and V. J. Rohay, Passive remediation of chlorinated volatile organic compounds using barometric pumping, in Proceedings of the Water Environment Federation: Innovative Solutions for Contaminated Site Management, Miami, FL, 1994. Rossabi, J., B. W. Jr. Colston, S. B. Brown, F. P. Milanovich, and L.T. Lee, In-situ, subsurface monitoring of vapor phase TCE using fiber optics, in Proceedings of the Third International Symposium-Field Screening Methods for Hazardous Waste and Toxic Chemicals, Las Vegas, Nevada, 1993.

Rossabi, J., and J. S. Haselow, Technology status report: off-gas treatment technologies for chlorinated volatile organic compound air emissions. WSRC-RP-92 473, Westinghouse Savannah River Company, Aiken, SC 29808, 1992.

Venugopalan, S., and J. Rossabi, Raman study of mesogenic transitions in 4,4'-di-npentyloxyazoxybenzene (C5)." J.Chem.Phys. 85(9), 1 November 1986. 


\author{
Lloyd “Bo" Stewart \\ Praxis Environmental Technologies, Inc., 1440 Rollins Road, Burlingame, CA \\ phone: (650) 224-3067 or (650) 548-9288 (work) \\ fax: (650) 548-9287 \\ email: Bo@Praxis-Enviro.com
}

\title{
Summary Information:
}

Dr. Lloyd "Bo" Stewart is Vice President and Principal Engineer of Praxis Environmental Technologies, Inc., an applied R\&D company he co-founded in 1992 to bring theoretical concepts into field practice. Dr. Stewart has developed, demonstrated and optimized numerous innovative environmental technologies for characterization and clean-up of chlorinated solvent and petroleum sites at DOD, DOE and industrial sites. Of particular relevance, Dr. Stewart, designed and managed all aspects of the first field demonstration of steam injection below the water table for the cleanup of dense nonaqueous phase liquids (DNAPLs).

\section{Education:}

1989 PhD. Mechanical Engineering, University of California Berkeley

1985 M.S. Mechanical Engineering, Georgia Institute of Technology

1983 B.S. Mechanical Engineering, North Carolina State University

\section{Selected Projects:}

2001-2006 Corrosion of Unexploded Ordnance in Soil Environments, Army Environmental Center (PI)

2003 Rebound Test Procedures and Data Evaluation in Support of Optimization and Closure of Soil Vapor Extraction Systems, Army Corps of Engineers (PI)

2000-2001 Development of Executable Program and Documentation for Public Domain Software to Evaluate Air Permeability Data Collected from Heterogeneous Vadose Zones, EPA (PI) 2000-2001 Theoretical and Experimental Evaluation of Techniques for Passive Maintenance of a Constant Temperature in a Narrow Annular Space Subjected to Transient Heat Loads, Applied Materials (PI) 1999-2001 Implementation and Evaluation of a Novel Approach for Dynamic Characterization and Remediation of Chlorinated Hydrocarbons in the Vadose Zone at Eight Sites on Castle AFB, CA (PI) 1999-2000 Comparison of Field Techniques for Evaluating Soil Permeability and Heterogeneities in the Vadose Zone, EPA (PI) 1998-2000 Field Demonstrations of Techniques for Evaluating and Optimizing Soil Vapor Extraction Systems at Castle, George, Mather, McClellan and Norton Air Force Bases, Air Force Center for Environmental Excellence (PI) 1997-2000 Field Demonstrations of Combined Characterization and Remediation in the Vadose Zone using Pneumatic Well Logging and Soil Vapor Extraction at Beale, Griffiss, and Nellis Air Force Bases, AFCEE (PI)

1997 Theoretical and Experimental Evaluation of Spray Cooling with Phase Change to Maintain a Constant Temperature on a Domed Surface Subjected to Transient Heat Loads, Applied Materials (PI) 1995-1997 Field Demonstration of Steam Injection as an Enhanced Source Removal Technology for Aquifer Restoration, Air Force Research Laboratory (PI) 1995-1996 Develop Public Domain Software and Documentation for Evaluating Potential Lead Migration Problems at Small Arms Ranges for distribution by the Army Environmental Center (PI)

1995 Develop a Generic Work Plan for Performing Remedial Technology Demonstrations at the National Test Sites, for use by Universities and other Researchers unfamiliar with Regulatory Requirements at Hazardous Waste Sites, Army Environmental Center (PI) 1995 Analyze and Model Field Data from a Test of Steam Injection in an Hydraulically Created Fracture, EPA (co-PI) 
1994-1998 Field Demonstration of In Situ Thermally Enhanced Extraction for Restoration of Aquifers Contaminated By Dense Nonaqueous Phase Liquids (DNAPLs), Operable Unit Two, Hill Air Force Base, UT, AFRL (PI)

\section{Patents:}

5,018,576 - Process for the In Situ Remediation of Subsurface Contamination by Combined Steam Injection and Vacuum Extraction (with K. Udell, J. Hunt, and N. Sitar)

\section{Selected Awards:}

Switzer Environmental Fellowship

Tau Beta Pi Engineering Honor Society

\section{Selected Professional Affiliations:}

American Society of Mechanical Engineers, National Groundwater Association, Association of Ground Water Scientists and Engineers, American Institute of Chemical Engineers, American Association for the Advancement of Science

\section{Journal Publications:}

L. Stewart and B. Packer, 2007. Corrosion rates of Carbon Steel, in Soil in Corrosion Science, accepted for publication June 2007.

L. Stewart, 2006. Steady, axisymmetric airflow in a multi-layered vadose zone, under revision for Water Resources Research.

M. Chendorain, L. Stewart and B. Packer, 2005. Corrosion of Unexploded Ordnance in Soil - Field Results, Environmental Science \& Technology, Vol. 39(8), pp. 2442-2447.

R.A. Hodges, R. Falta and l. Stewart, 2004. Controlling steam flood migration using air injection, Environmental Geosciences, Vol. 11, No. 4, pp. 221-238.

L. Stewart, 2003. Overview of Rebound Test Procedures and Data Evaluation, included as Appendix F to the Army Corp of Engineer's Soil Vapor Extraction and Bioventing Engineer's Manual, Omaha, NE L. Stewart and K. Udell, 1988. Mechanisms of Residual Oil Displacement by Steam Injection, SPE Reservoir Engineering, Vol. 3, pp. 1233-1242, November 1988.

\section{Selected Conference Proceedings:}

“Field Demonstrations of Thermally Enhanced Extraction,” Proceedings, Abiotic In Situ Technologies for Groundwater Remediation Conference, August 31 - Sept 2, 1999, Dallas, TX, EPA/625/R-99/012, August 2000.

"Field Demonstration of Thermally Enhanced Extraction for DNAPL Source Removal," with J. Ginn and S. Hicken, in Nonaqueous-Phase Liquids: Remediation of Chlorinated and Recalcitrant Compounds, Wickramanayake and Hinchee (Eds.), Battelle Press, Columbus, OH, 256 pp., 1998.

"Combined Steam Injection and Vacuum Extraction for Aquifer Cleanup," with K.S. Udell, presented at the Annual Meeting of the International Association of Hydrogeologists, Calgary, April 1990.

"The Effects of Gravity and Multiphase Flow on the Stability of Steam Condensation Fronts in Porous Media," with K.S. Udell, Multiphase Transport in Porous Media, ASME HTD Vol. 127, December 1989. "Mechanisms of In Situ Remediation of Soil and Groundwater Contamination by Combined Steam Injection and Vacuum Extraction," with K.S. Udell, Paper No. 119d presented at the Symposium on Thermal Treatment of Radioactive and Hazardous Waste at the AIChE Annual Meeting, San Francisco, November 1989.

"The Effect of Gravity on Steam Propagation in Porous Media," with K.S. Udell and M.D. Basel, Multiphase Transport in Porous Media, ASME HTD Vol. 91, December, 1987. 


\section{Appendix C}

\section{Extended Evaluation of Soil Vapor Extraction}


The following analysis provides a relatively detailed presentation about a lower cost soil vapor extraction option - "SVE Lite". The evaluation first presents information for the Oil Landfarm (SWMU 1) and then for the C-720 spill sites (SWMU 211A/211B).

\section{Evaluation of Oil Landfarm (SWMU 1) Source Term in the UCRS and Remedy}

This review considered TCE as the contaminant of concern. As reported in the SI Report, the area of TCE contamination at Oil Landfarm (SWMU 1) was found to cover approximately $8,712 \mathrm{ft}^{2}(0.2$ acre). The thickness of the contaminated mass within the UCRS was estimated to be 55-ft or to the top of the RGA. The piezometric surface for the RGA resides a depth of 40 to 60 feet deep and the UCRS holds a limited amount of water that can easily be removed and managed, as needed. To define the extent of contamination at varying depths in the SI, the contaminated mass was divided into six layers as provided in Table F.22 from Appendix F of the SI Report. Each of the six layers, beginning from the ground surface, is 10 -ft thick; however, only the top 5-ft of Layer 6 was used in the volume and mass calculations to correctly approximate the 55-ft thickness of the UCRS at SWMU 1. The total mass of TCE in the UCRS at Oil Landfarm (SWMU 1) was estimated to be $273 \mathrm{~kg}$ (600 pounds). An order-of-magnitude calculation with the measured soil concentrations from the SI indicates this estimate is reasonable.

Table F.22 (from SI Appendix F). Summary of source term TCE characteristics developed by SADA for SWMU 1

\begin{tabular}{|c|c|c|c|c|c|c|}
\hline Layer & $\begin{array}{c}\text { Depth } \\
\text { (ft) }\end{array}$ & $\begin{array}{c}\text { Average } \\
\text { Soil Conc } \\
\text { (mg/kg) }\end{array}$ & $\begin{array}{l}\text { Area } \\
\left(\mathbf{f t}^{2}\right)\end{array}$ & $\begin{array}{c}\text { Volume } \\
\left(\mathbf{f t}^{3}\right)\end{array}$ & $\begin{array}{c}\text { Mass } \\
\text { (g) }\end{array}$ & $\begin{array}{c}\text { Estimated } \\
\text { Vapor Conc } \\
\text { (mg/L) }\end{array}$ \\
\hline Layer 1 & $00-10$ & 7.59 & 4,375 & 43,750 & 13,723 & 10.6 \\
\hline Layer 2 & $10-20$ & 110.8 & 3,125 & 31,250 & 143,177 & 155 \\
\hline Layer 3 & $20-30$ & 17.6 & 6,250 & 62,500 & 45,503 & 24.6 \\
\hline Layer 4 & $30-40$ & 13.0 & 5,625 & 56,250 & 30,283 & 18.1 \\
\hline Layer 5 & $40-50$ & 13.6 & 5,625 & 56,250 & 31,516 & 19.0 \\
\hline Layer 6 & $50-55$ & 5.74 & 7,500 & 37,500 & 8,902 & 8.0 \\
\hline TOTAL & & & & 287,500 & 273,104 & \\
\hline
\end{tabular}

A column was added to Table F.22 for the estimated TCE vapor concentration. The vapor concentration was calculated from equilibrium partitioning of the soil concentration between adsorbed, dissolved and volatilized phases. The soil and TCE properties provided in Tables F.26 and F.27 were used in the calculations. These soil and vapor concentrations also correspond to TCE concentrations in the pore water in the ten's of parts per million or three to four orders of magnitude above the EPA's maximum contaminant level. Such high pore water concentrations suggest droplets of pure TCE may exist in the subsurface. Specifically, in Layer 2, the pore water concentration in equilibrium with a soil concentration of $110.8 \mathrm{mg} / \mathrm{kg}$ is estimated to be about 400 parts per million, or about one-third of the solubility limit of TCE. 
The preferred remedy for the UCRS at Oil Landfarm (SWMU 1) as described in the FFS is, Alternative 8-In Situ Source Treatment Using Enhanced In Situ Bioremediation with Interim Land Use Controls. This remedy involves the installation of deep gravity feed wells along with a shallow infiltration gallery for the system. A bioamendment composed of microbes, nutrients, and/or reductants, as necessary, would be injected or placed in the wells and gallery to allow the amendment to enter the subsurface either by gravity or under pressure. However, the site is assumed to have a relatively low permeability; therefore it is highly probable that the infiltrating water and amendments will travel through preferential flow paths and will not have adequate or efficient contact with the contamination.

SVE was considered as part of two alternatives in the focused feasibility study: Alternative 5: In Situ Thermal Treatment with Interim LUCs and Alternative 7: In Situ Soil Flushing and Source Treatment Using Multiphase Extraction with Interim LUCs. Yet, SVE alone was not adequately considered for the TCE source in the UCRS. Evaluation of SVE was abandoned presumably because the source was in the shallow vadose zone and the technical constraints of constructing a surface barrier to impede surface flow at an industrial setting (DOE 2011a). The experience of the ITR team is that natural anisotropy in the soil promotes predominantly horizontal vapor flow during SVE and a surface barrier is unnecessary. A pilot test of SVE is highly recommended to determine the permeability of the vadose zone and obtain a measure of potential mass removal rates via SVE.

The ITR utilized the model of SVE presented in the Army Corps of Engineers, Soil Vapor Extraction and Bioventing, Engineers Manual EM-1110-1-4001 (2002), "Appendix F, Overview of Rebound Test Procedures and Data Evaluation" to evaluate the potential impact of SVE at SWMU 1. Appendix F is attached. This model conceptualizes the vadose zone as having two regions: mobile (i.e., coarse-grained soils) and immobile (i.e., fine-grained soils). The immobile soil generally has static pore water and a high water content. The model assumes vapor flows through the coarse soil and that contaminant must be transported by diffusion or pore water advection from fine grained units prior to extraction (i.e., classic mass transfer constraints for SVE). The two-region model has been applied at over twenty sites that provide reasonable estimates for input parameters representing Oil Landfarm (SWMU 1) that are not available from SI Report Tables F.26 and F.27. These parameters are listed in Table 1. The volume of contaminated soil and the initial vapor concentrations are from Table F.22. The vadose zone is assumed to be roughly one-third mobile and two-thirds immobile with an initial mass of $271 \mathrm{~kg}$ of TCE based on the average equilibrium TCE vapor concentration from Table F.22. Based on experience at other sites, the characteristic thickness, i.e., the length scale for diffusion of contaminants from immobile zones, is assumed to be about 2.5 feet. 
Table 1. Parameters for Two-Region Modeling of TCE Extraction at Oil Landfarm (SWMU 1)

\begin{tabular}{|c|c|c|c|}
\hline Soil Property & Units $^{a}$ & $\begin{array}{c}\text { Mobile } \\
\text { Zone }\end{array}$ & $\begin{array}{c}\text { Immobile } \\
\text { Zone }\end{array}$ \\
\hline Initial Vapor Concentration & $\mathrm{ug} / \mathrm{L}$ & 44,000 & 44,000 \\
\hline Porosity & ND & 0.45 & 0.45 \\
\hline Water Saturation (vol) & ND & 0.25 & 0.40 \\
\hline Grain Density & $\mathrm{g} / \mathrm{cm}^{3}$ & 2.66 & 2.66 \\
\hline Characteristic Thickness & $\mathrm{m}$ & - & 0.762 \\
\hline Characteristic Volume & $\mathrm{m}^{3}$ & 2,713 & 5,427 \\
\hline $\mathrm{K}_{\mathrm{d}}$ & $\mathrm{L} / \mathrm{kg}$ & 0.0752 & 0.0752 \\
\hline Degradation Rate & $1 / \mathrm{yr}$ & 0 & 0 \\
\hline TCE Properties & & & \\
\hline Henry’s Constant & ND & \multicolumn{2}{|c|}{0.38} \\
\hline Octanol-Water Partition & ND & \multicolumn{2}{|c|}{200} \\
\hline Diffusion Coefficient in Air & $\mathrm{m}^{2} /$ day & \multicolumn{2}{|c|}{0.68} \\
\hline
\end{tabular}

${ }^{\mathrm{a}} \mathrm{ND}=$ dimensionless

Results of the SVE modeling are illustrated in Figures 1 and 2 below. Figure 1 illustrates the vapor concentration histories in the mobile and immobile zones over time with a vapor extraction rate of 60 standard cubic feet per minute (scfm). This flow rate can be achieved with a 1.5-horsepower regenerative blower operating at a vacuum of 50 inches of water. Such a small blower utilizes about 1,500 watts of energy and can be powered with a standard, single-phase, 20-amp outlet. The mobile zone vapor concentration history shows a steep decline as this region is initially swept and then mass transfer constraints limit the mass extraction rate. The difference between the mobile and immobile zone vapor concentrations represents the driving concentration gradient for mass transfer. The estimated mass remaining at the site over time is illustrated in Figure 2. For the rough estimates of this review, the model suggests nearly $90 \%$ of the source TCE mass in the UCRS at Oil Landfarm (SMWU 1) could be extracted in about 7 months of SVE at the low flow rate of $60 \mathrm{scfm}$. 


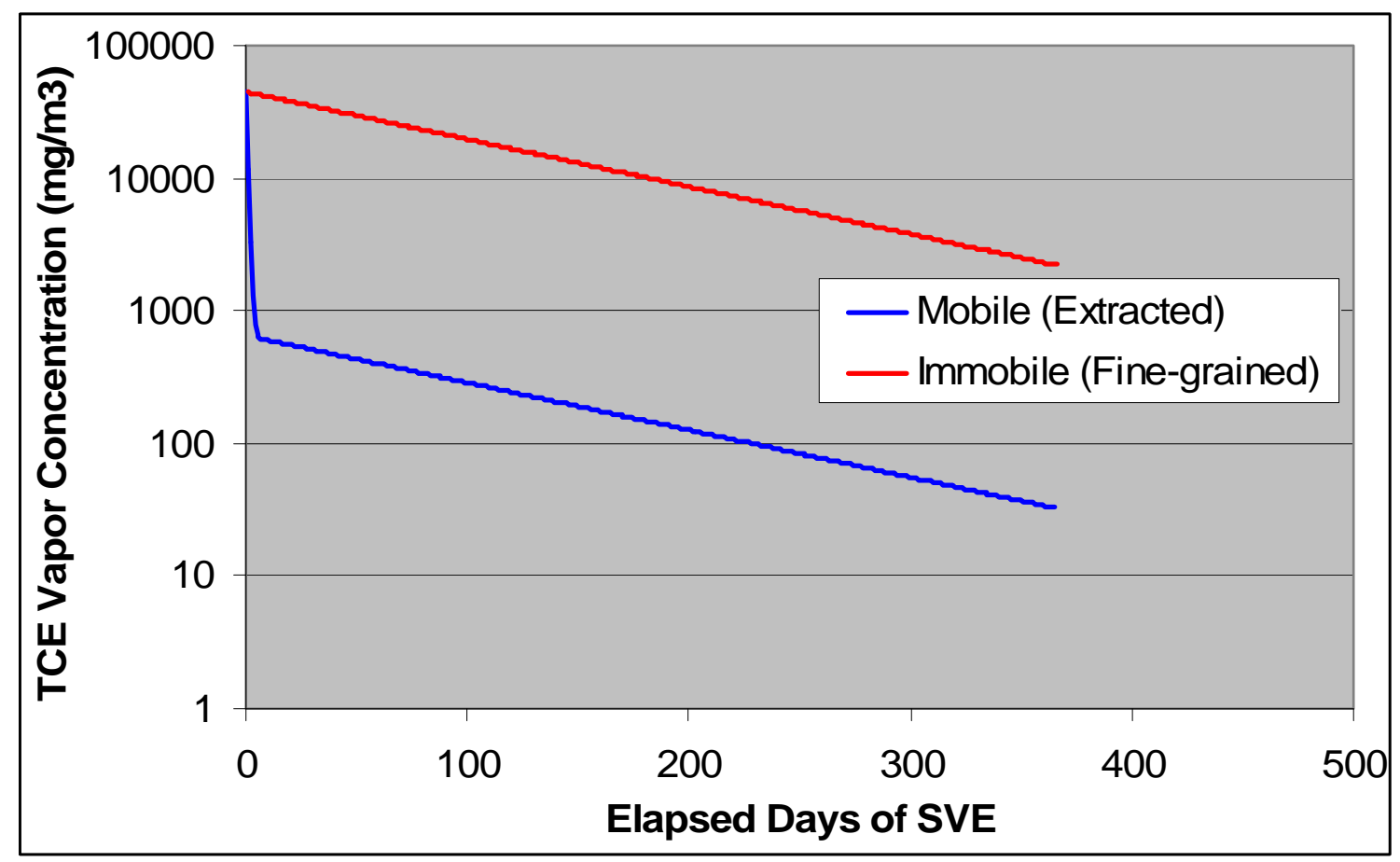

Figure 1. Modeled TCE Vapor Concentrations at SWMU 1 during SVE at 60 scfm

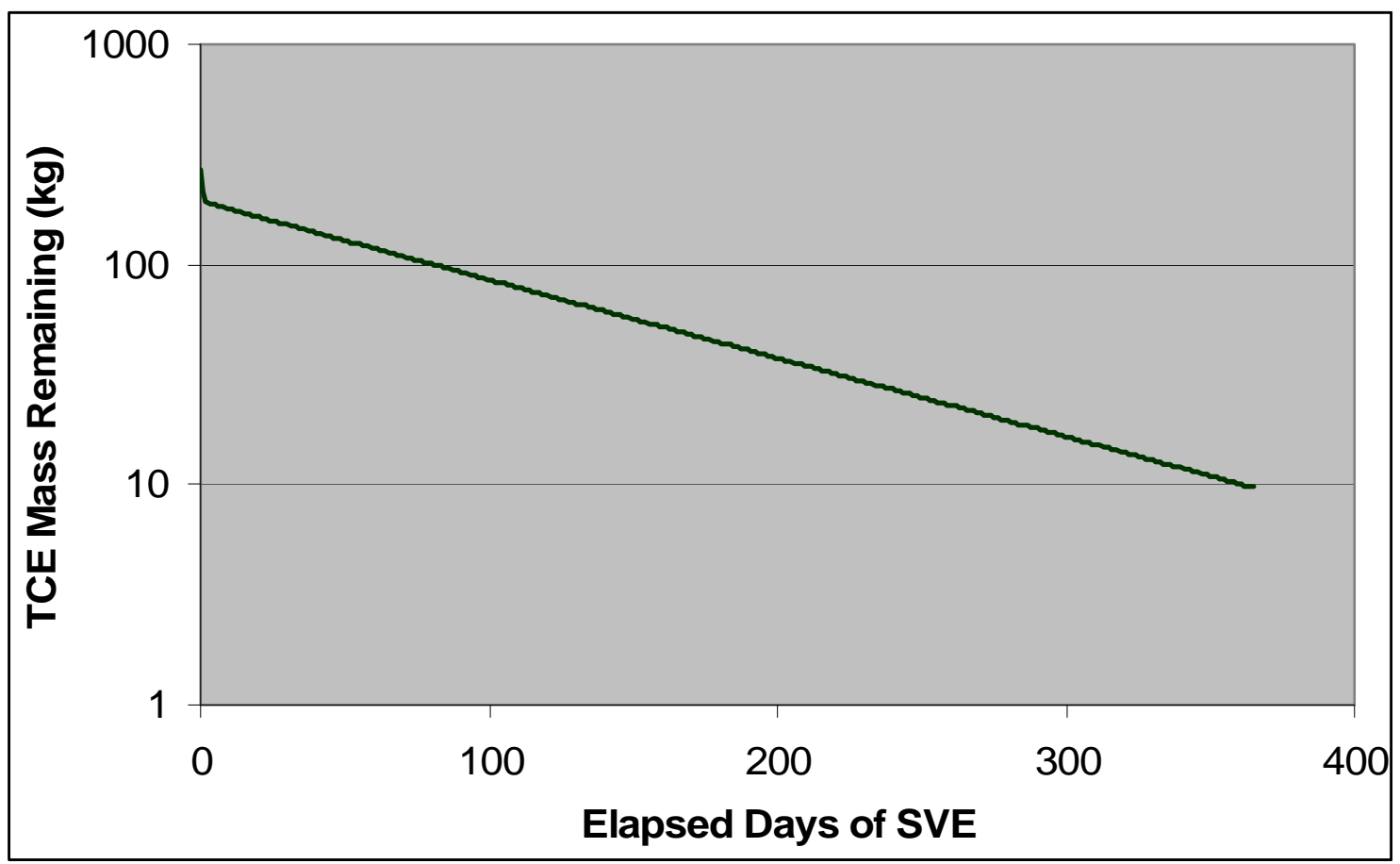

Figure 2. Modeled TCE Mass Remaining in the UCRS at SWMU 1 during SVE at $60 \mathrm{scfm}$ 
A photograph of an SVE system similar to the one modeled in this exercise is provided in Figure 3 and shows the small footprint required. That system did not require any vapor treatment; however, the TCE vapor concentrations at Oil Landfarm (SWMU 1) would require treatment before atmospheric discharge. For the mass of TCE estimated at Oil Landfarm (SWMU 1), the appropriate vapor treatment technology would be activated carbon in 2,000-pound vessels. For a total TCE mass of $273 \mathrm{~kg}$ (600 pounds), the total activated carbon requirement would be about 5,000 pounds. Hence, a pair of 2,000pound vessels should be deployed. After breakthrough in the front vessel, it would be sent off-site for treatment and a new vessel placed in line. The total activated carbon requirement, assuming the mass estimate is accurate, would be about 6,000 pounds. The total cost of this carbon including purchase, disposal and rental of the vessels would be about $\$ 30,000$ and makeup the majority of the capital cost of the system. A small regenerative blower with simple control panel can be purchased for a few thousand dollars. The system would also require a water (condensate) knockout tank between the well and blower. The presence of co-contaminants (e.g., 99Tc) or the need to dewater would increase costs (but the projected costs should fall well below the costs tabulated in the PP.

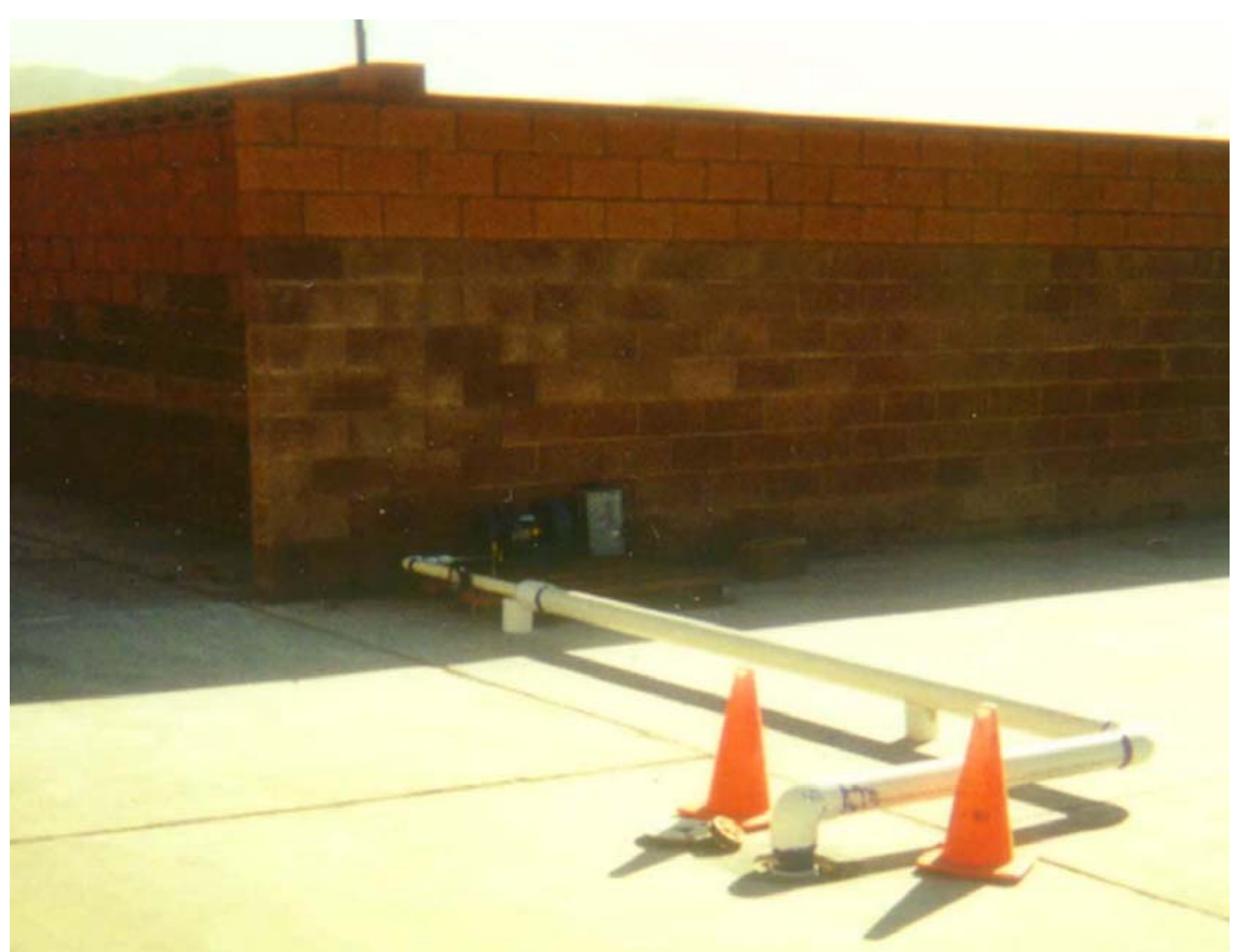

Figure 3. Photograph of an SVE System Operating at $60 \mathrm{scfm}$ without Vapor Treatment 


\section{Evaluation of C-720 Building Area Source Term (SWMU 211A/211B) in the UCRS and Remedy}

This review only considered TCE as the contaminant of concern. As reported in the SI Report, the area of TCE contamination at the C-720 Building Area (SWMU 211A/211B) was found to cover approximately $15,000 \mathrm{ft}^{2}(0.2$ acre). The thickness of the contaminated mass within the UCRS was estimated to be $60 \mathrm{ft}$ or to the top of the RGA. The water table resides near the interface between the UCRS and RGA. To define the extent of contamination at varying depths in the SI, the contaminated mass was divided into six layers as provided in Table F.23 from Appendix F of the SI Report. Each of the six layers, beginning from the ground surface, is $10-\mathrm{ft}$ thick. The total mass of TCE in the UCRS at the C-720 Building Area (SWMU 211A/211B) was estimated to be $111 \mathrm{~kg}$ (245 pounds). An order-of-magnitude calculation with the measured soil concentrations from the SI indicates this estimate is reasonable.

Table F.23 (from SI Appendix F). Summary of source term characteristics developed by SADA for the C-720 Building Area (SWMU 211A/211B)

\begin{tabular}{|ccccccc|}
\hline Layer & Depth & $\begin{array}{c}\text { Average } \\
\text { Soil Conc }\end{array}$ & Area & Volume & Mass & $\begin{array}{c}\text { Estimated } \\
\text { Vapor Conc } \\
\text { (mg/L) }\end{array}$ \\
\hline Layer 1 & $00-10$ & 2.96 & 7,500 & 75,000 & 13,723 & 4.1 \\
Layer 2 & $10-20$ & 6.37 & 7,500 & 75,000 & 143,177 & 8.9 \\
Layer 3 & $20-30$ & 11.9 & 15,000 & 150,000 & 45,503 & 16.6 \\
Layer 4 & $30-40$ & 1.55 & 6,875 & 68,750 & 30,283 & 2.2 \\
Layer 5 & $40-50$ & 1.20 & 6,875 & 68,750 & 31,516 & 1.7 \\
Layer 6 & $50-60$ & 0.10 & 6,875 & 68,750 & 8,902 & 0.14 \\
TOTAL & & & & 506,250 & 110,922 & \\
& & & & & & \\
\hline
\end{tabular}

A column was added to Table F.23 for the estimated TCE vapor concentration. The vapor concentration was calculated from equilibrium partitioning of the soil concentration between adsorbed, dissolved and volatilized phases. The soil and TCE properties provided in Tables F.26 and F.27 were used in the calculations. These soil and vapor concentrations also correspond to TCE concentrations in the pore water in the ten's of parts per million or about three orders of magnitude above the EPA's maximum contaminant level. Such high pore water concentrations suggest droplets of pure TCE could exist in the subsurface. Specifically, in Layer 3, the pore water concentration in equilibrium with a soil concentration of $11.9 \mathrm{mg} / \mathrm{kg}$ is estimated to be about 60 parts per million, or about $6 \%$ of the solubility limit of TCE.

The preferred remedy for the UCRS at Building C-720 as described in the FFS is, Alternative 2-Long-Term Monitoring with Interim Land Use Controls. This remedy involves primarily monitoring at the site and access controls. SVE was considered as part of two alternatives in the FFS: Alternative 5: In Situ Thermal Treatment with Interim LUCs and Alternative 7: In Situ Soil Flushing and Source Treatment Using 
Multiphase Extraction with Interim LUCs. Yet, SVE alone was not adequately considered for the TCE source in the UCRS. Evaluation of SVE was abandoned presumably because the source was in the shallow vadose zone and the technical constraints of constructing a surface barrier to impede surface flow at an industrial setting (DOE 2011a). The experience of the ITR team is that natural anisotropy in the soil promotes predominantly horizontal vapor flow during SVE and a surface barrier is unnecessary. A pilot test of SVE is highly recommended to determine the permeability of the vadose zone and obtain a measure of potential mass removal rates via SVE.

The ITR utilized the model of SVE, described above and, presented in the Army Corps of Engineers, Soil Vapor Extraction and Bioventing, Engineers Manual EM-1110-1-4001 (2002), “Appendix F, Overview of Rebound Test Procedures and Data Evaluation” to evaluate the potential impact of SVE at Building C-720 (SWMU 211A/211B). The tworegion model has been applied at over twenty sites that provide reasonable estimates for input parameters representing Building C-720 that are not available from SI Report Tables F.26 and F.27. These parameters are listed in Table 2. The volume of contaminated soil and the initial vapor concentrations are from Table F.23. The vadose zone is assumed to be roughly one-third mobile and two-thirds immobile with an initial mass of $111 \mathrm{~kg}$ of TCE based on the average equilibrium TCE vapor concentration from Table F.23. Based on experience at other sites, the characteristic thickness, i.e., the length scale for diffusion of contaminants from immobile zones, is assumed to be about 2.5 feet.

Table 2. Parameters for Two-Region Modeling of TCE Extraction at the C-720 Building Area

\begin{tabular}{|c|c|c|c|}
\hline Soil Property & Units $^{\mathrm{a}}$ & $\begin{array}{l}\text { Mobile } \\
\text { Zone }\end{array}$ & $\begin{array}{c}\text { Immobile } \\
\text { Zone }\end{array}$ \\
\hline Initial Vapor Concentration & $\mathrm{ug} / \mathrm{L}$ & 10,000 & 10,000 \\
\hline Porosity & ND & 0.45 & 0.45 \\
\hline Water Saturation (vol) & ND & 0.25 & 0.40 \\
\hline Grain Density & $\mathrm{g} / \mathrm{cm}^{3}$ & 2.66 & 2.66 \\
\hline Characteristic Thickness & $\mathrm{m}$ & - & 0.762 \\
\hline Characteristic Volume & $\mathrm{m}^{3}$ & 4,779 & 9,557 \\
\hline $\mathrm{K}_{\mathrm{d}}$ & $\mathrm{L} / \mathrm{kg}$ & 0.0846 & 0.0846 \\
\hline Degradation Rate & $1 / \mathrm{yr}$ & 0 & 0 \\
\hline \multicolumn{4}{|l|}{ TCE Properties } \\
\hline Henry’s Constant & ND & \multicolumn{2}{|c|}{0.38} \\
\hline Octanol-Water Partition & ND & \multicolumn{2}{|c|}{200} \\
\hline Diffusion Coefficient in Air & $\mathrm{m}^{2} /$ day & \multicolumn{2}{|c|}{0.68} \\
\hline
\end{tabular}

${ }^{\mathrm{a}} \mathrm{ND}=$ dimensionless

Results of the SVE modeling are illustrated in Figures 4 and 5 below. Figure 4 illustrates the vapor concentration histories in the mobile and immobile zones over time with a vapor extraction rate of $60 \mathrm{scfm}$. As described previously, this flow rate can be achieved 
with a 1.5-horsepower regenerative blower operating at a vacuum of 50 inches of water. Such a small blower utilizes about 1,500 watts of energy and can be powered with a standard, single-phase, 20 -amp outlet. The mobile zone vapor concentration history shows a steep decline as this region is initially swept and then mass transfer constraints limit the mass extraction rate. The difference between the mobile and immobile zone vapor concentrations represents the driving concentration gradient for mass transfer. The estimated mass remaining at the site over time is illustrated in Figure 5. For the rough estimates of this review, the model suggests nearly $90 \%$ of the source TCE mass in the UCRS at Building C-720 (SWMU 211A/211B) could be extracted in about 6 months of SVE at the low flow rate of $60 \mathrm{scfm}$.

The TCE vapor concentrations at Building C-720 (SWMU 211A/211B) would require treatment before atmospheric discharge. For the mass of TCE estimated at Building C720 (SWMU 211A/211B), the appropriate vapor treatment technology would be activated carbon in 2,000-pound vessels. For a total TCE mass of $111 \mathrm{~kg}$ (245 pounds), the total activated carbon requirement would be about 2,000 pounds. Hence, a pair of 2,000-pound vessels should be deployed. Theoretically, the site would be effectively remediated at breakthrough in the front vessel. Both vessels would be sent off-site for treatment and disposal. The total activated carbon requirement, assuming the mass estimate is accurate, would be about 4,000 pounds. The total cost of this carbon including purchase, disposal and rental of the vessels would be about $\$ 20,000$ and makeup the majority of the capital cost of the system. A small regenerative blower with simple control panel can be purchased for a few thousand dollars. The system would also require a simple water (condensate) knockout tank between the well and blower. The presence of co-contaminants (e.g., 99Tc) or the need to dewater would increase costs (but the projected costs should fall well below the costs tabulated in the PP. 


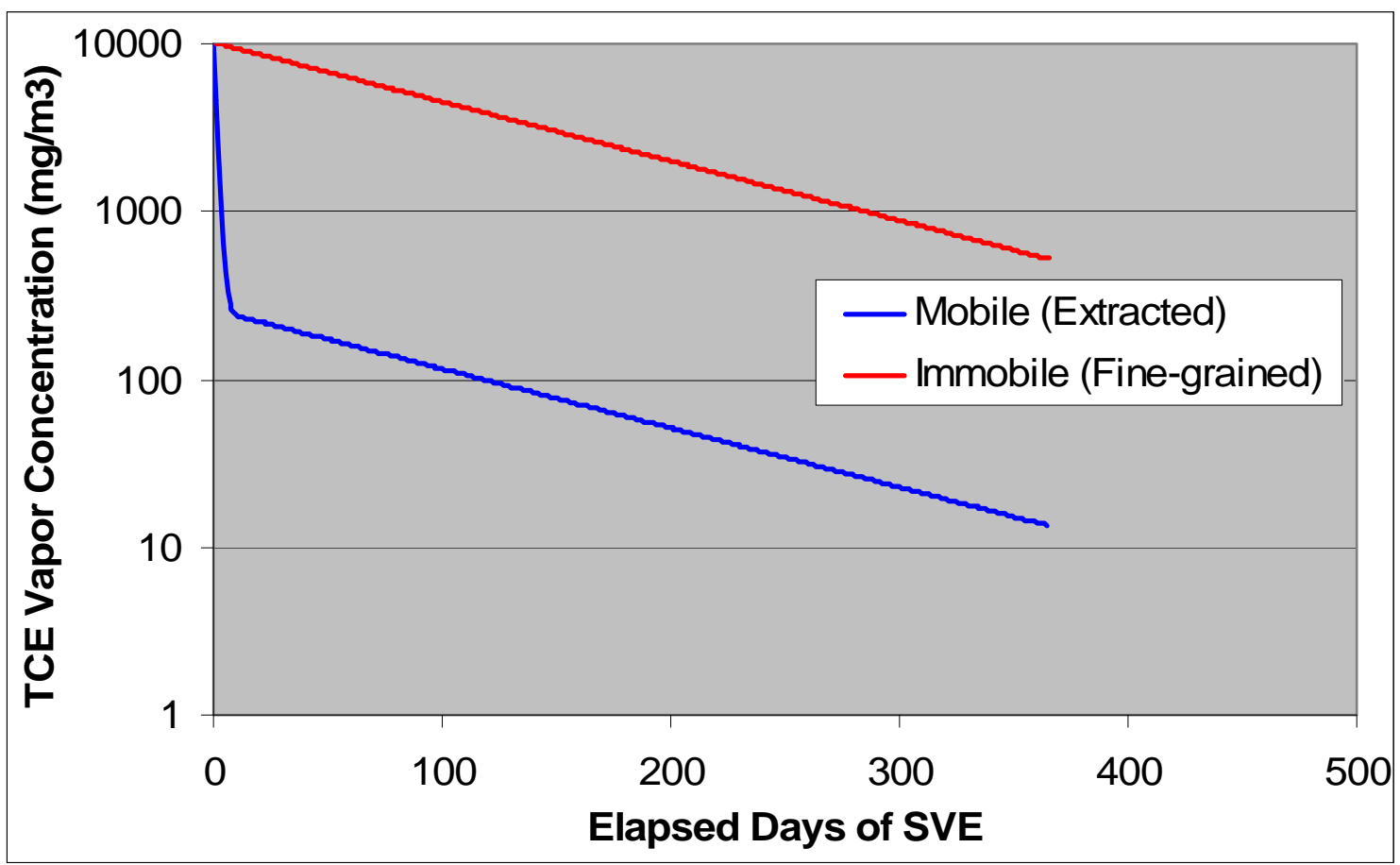

Figure 4. Modeled TCE Vapor Concentrations at Bldg C-720 during SVE at 60 scfm

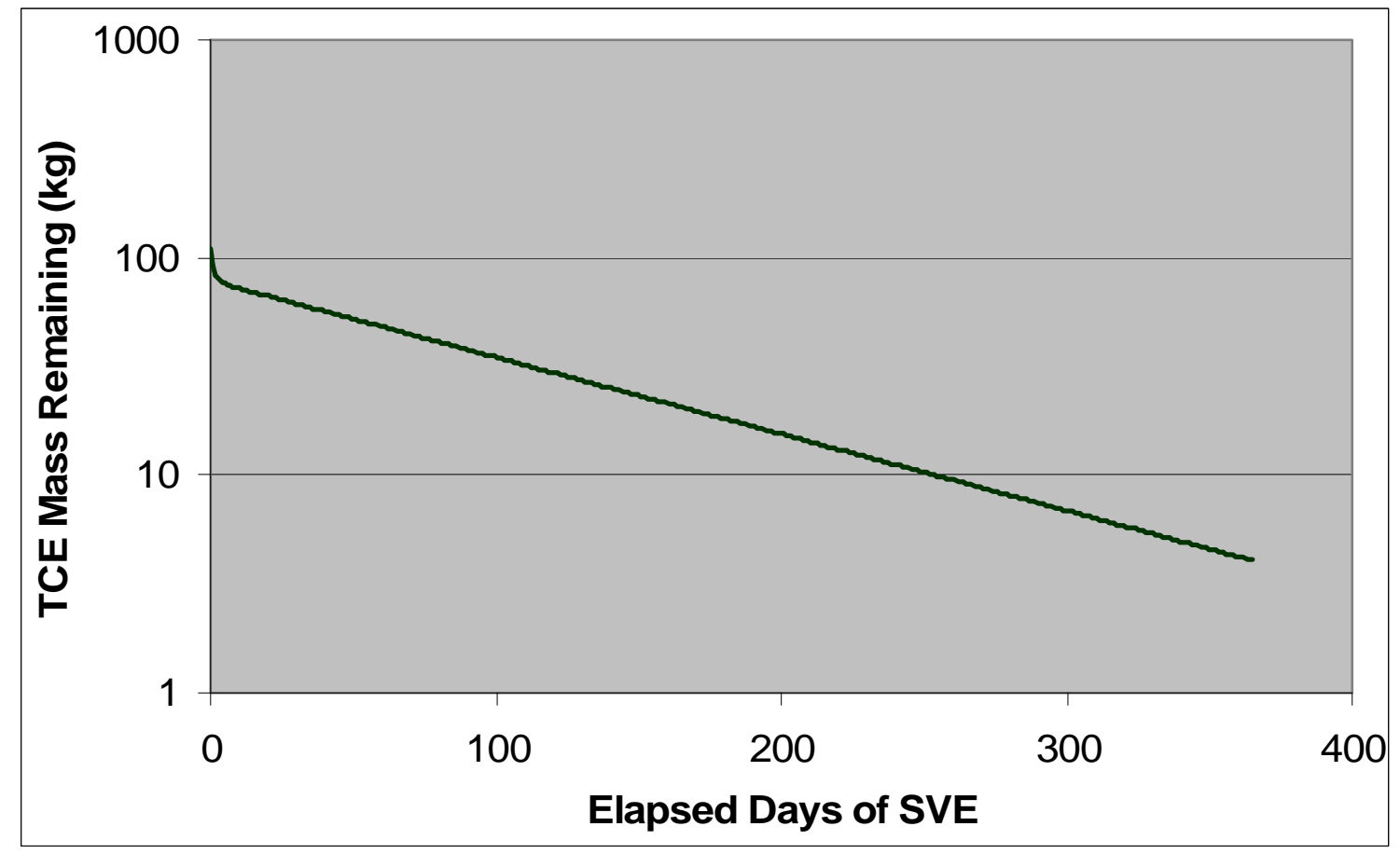

Figure 5. Modeled TCE Mass Remaining in UCRS at Bldg C-720 during SVE at 60 scfm 